\title{
The ENSO signal in atmospheric composition fields: emission-driven versus dynamically induced changes
}

\author{
A. Inness ${ }^{1}$, A. Benedetti ${ }^{1}$, J. Flemming ${ }^{1}$, V. Huijnen ${ }^{2}$, J. W. Kaiser ${ }^{3}$, M. Parrington ${ }^{1}$, and S. Remy ${ }^{4}$ \\ ${ }^{1}$ ECMWF, Reading, UK \\ ${ }^{2}$ Royal Netherlands Meteorological Institute, De Bilt, the Netherlands \\ ${ }^{3}$ Max Planck Institute for Chemistry, Mainz, Germany \\ ${ }^{4}$ Laboratoire de Météorologie Dynamique, Paris, France \\ Correspondence to: A. Inness (a.inness@ecmwf.int)
}

Received: 19 March 2015 - Published in Atmos. Chem. Phys. Discuss.: 13 May 2015

Revised: 22 July 2015 - Accepted: 23 July 2015 - Published: 14 August 2015

\begin{abstract}
The El Niño-Southern Oscillation (ENSO) not only affects meteorological fields but also has a large impact on atmospheric composition. Atmospheric composition fields from the Monitoring Atmospheric Composition and Climate (MACC) reanalysis are used to identify the ENSO signal in tropospheric ozone, carbon monoxide, nitrogen oxide and smoke aerosols, concentrating on the months October to December. During El Niño years, all of these fields have increased concentrations over maritime South East Asia in October. The MACC Composition Integrated Forecasting System (C-IFS) model is used to quantify the relative magnitude of dynamically induced and emission-driven changes in the atmospheric composition fields. While changes in tropospheric ozone are a combination of dynamically induced and emission-driven changes, the changes in carbon monoxide, nitrogen oxides and smoke aerosols are almost entirely emission-driven in the MACC model. The ozone changes continue into December, i.e. after the end of the Indonesian fire season while changes in the other fields are confined to the fire season.
\end{abstract}

\section{Introduction}

The El Niño-Southern Oscillation (ENSO) is the dominant mode of variability in the tropics (e.g. Allan et al., 1996). It not only affects meteorological fields, but it also has a large impact on atmospheric composition too, for example on ozone $\left(\mathrm{O}_{3}\right)$, carbon monoxide $(\mathrm{CO})$, nitrogen oxides $\left(\mathrm{NO}_{x}\right)$ and aerosols (e.g. Logan et al., 2008; Ziemke and Chandra,
2003; Chandra et al., 2002; Wang et al., 2004). As a result of an eastwards shift of the warm sea surface temperatures (SST) and the large-scale Walker circulation anomaly in the tropical Pacific during El Niño years, downward motion is increased and convection and precipitation are reduced over the western Pacific and the Maritime Continent. During La Niña conditions the opposite dynamical effects occur. Fire emissions over Indonesia show a large interannual variability (IAV), with largest emissions during El Niño years (e.g. van der Werf et al., 2006; Kaiser et al., 2012), when drought conditions and anthropogenic biomass burning lead to big wild fires (Duncan et al., 2003; Lyon, 2004; Page et al., 2002) that emit large amounts of trace gases and aerosols. During El Niño years tropospheric $\mathrm{O}_{3}$ columns $\left(\mathrm{TCO}_{3}\right)$ are decreased over the central and eastern Pacific and increased over the western Pacific and Indonesia, while CO concentrations and aerosols from biomass burning increase over Indonesia. Specific humidity changes in the upper troposphere are anti-correlated with the changes in $\mathrm{TCO}_{3}$ (e.g. Chandra et al., 2007).

These atmospheric composition changes were found in observations (Chandra et al., 1998; Ziemke and Chandra, 1999; Fujiwara et al., 1999; Chandra et al., 2007; Logan et al., 2008) and confirmed by modelling studies (Hauglustaine et al., 1999; Sudo and Takashashi, 2001; Chandra et al., 2002; Doherty et al., 2006; Chandra et al., 2009; Nassar et al., 2009) which also tried to quantify the relative importance of the dynamically induced and the emissiondriven atmospheric composition changes. The reasons for the $\mathrm{TCO}_{3}$ increase over the western Pacific and Indonesia dur- 
ing El Niño years are (i) changes in the vertical transport that lead to enhanced downward transport of $\mathrm{O}_{3}$-rich air from the upper troposphere (and perhaps stratosphere) to the middle and lower troposphere, and reduced transport of $\mathrm{O}_{3}$-poor air from the lower troposphere into the upper troposphere; (ii) a longer chemical lifetime of $\mathrm{O}_{3}$ because of reduced humidity which affects the concentrations of the hydroxyl radical $(\mathrm{OH})$ and hence the photochemical loss of tropospheric $\mathrm{O}_{3}$; and (iii) enhanced photochemical production of $\mathrm{O}_{3}$ in the lower troposphere because of increased concentrations of $\mathrm{O}_{3}$ precursors from biomass burning, such as $\mathrm{NO}_{x}, \mathrm{CO}$ or hydrocarbons. We refer to (i) and (ii) as "dynamically induced changes" and to (iii) as "emission-driven changes" throughout this paper.

For El Niño events with large fires over Indonesia, such as in 1997 and 2006, the $\mathrm{TCO}_{3}$ changes due to dynamics and due to increased emissions can be of similar magnitude (Sudo and Takahashi, 2001; Chandra et al., 2002; Chandra et al,. 2009), while for weaker events, such as the 2004 El Niño, the dynamical impact dominates (Chandra et al., 2007).

The changes in $\mathrm{CO}$ are mainly emission-driven (Logan et al., 2008; Chandra et al., 2009; Voulgarakis et al., 2010) and of smaller horizontal scale than the $\mathrm{O}_{3}$ anomalies, but dynamical interactions due to changes in water vapour $\left(\mathrm{H}_{2} \mathrm{O}\right)$ and hence $\mathrm{OH}$ can also play a role. $\mathrm{CO}$ is increased over the western Pacific and the Maritime Continent during El Niño because of increased emissions from fires and the increased chemical lifetime due to reduced $\mathrm{OH}$. The $\mathrm{CO}$ anomaly over Indonesia is usually gone by December (Logan et al., 2008; Chandra et al., 2009), after the end of the biomass burning season, while the $\mathrm{O}_{3}$ anomaly continues.

Large Indonesian wildfires can affect the air quality over South East Asia. Aouizerats et al. (2015) investigated how the transport of biomass burning emissions from Sumatra affected the air quality in Singapore. They found that $21 \%$ of the $\mathrm{PM}_{10}$ loading in Singapore during July to October 2006 was due to Sumatran fires, and that Sumatran fires were responsible for about half of the days with $\mathrm{PM}_{10}$ concentrations greater than $50 \mu \mathrm{g} \mathrm{m}^{-3}$ while the other half was due to local anthropogenic pollution and contributions from smaller fires. The impact of fire emissions on atmospheric aerosol concentrations is of particular interest because of the potential feedback of fire-induced aerosols on climate. Several studies have looked at the correlations between ENSO and aerosols or atmospheric haze produced by the Indonesian fires. Wang et al. (2004) used visibility data over Sumatra as an indicator of biomass burning and found that haze events were strongly correlated with El Niño during the 1973 to 2003 period. Tosca et al. (2010) used satellite data and modelling studies and found that the aerosol optical depth (AOD) over Indonesia had a large IAV that was driven by wild fires during periods of El Niño-induced droughts. Their modelling study showed that the fire-emitted aerosols could initiate a positive feedback loop. The aerosols acted to intensify drought over the biomass burning regions. The aerosols also reduced land and sea surface temperatures, and hence suppressed convection and precipitation in the area. Podgorny et al. (2003) looked at the feedback between El Niño and the Indonesian biomass burning of 1997 and also found that the haze from the fires reduced the solar radiation absorbed by the equatorial Indian Ocean and increased the solar heating of the atmosphere, thus raising the possibility of dynamical feedback of the smoke forcing on ENSO. Chung and Ramanathan (2003) carried out modelling studies to assess the remote impact of changes in the South Asian haze and found that fluctuations in the absorbing aerosol forcing could affect the interannual climate variability in the tropics (and extratropics). An extended haze forcing could remotely suppress convection in the equatorial western Pacific and lead to an oceanatmosphere response that was very similar to El Niño-like warming.

As part on the EU FP7-funded Monitoring Atmospheric Composition and Climate (MACC) project (www. copernicus-atmosphere.eu), a 10-year reanalysis of atmospheric composition (Inness et al., 2013) was constructed. This reanalysis provides fields of chemically active gases, for example $\mathrm{CO}, \mathrm{O}_{3}$, and $\mathrm{NO}_{x}$, as well as aerosols globally for both the troposphere and the stratosphere for the years 2003 to 2012. It gives us the unprecedented possibility to assess the impact of ENSO on atmospheric composition using an observationally constrained, continuous, threedimensional atmospheric composition data set with a resolution of about $80 \mathrm{~km}$, which is greater than the resolutions used in most previous modelling studies. In this paper we show that the MACC reanalysis shows the ENSO-induced anomalies in $\mathrm{O}_{3}, \mathrm{CO}, \mathrm{NO}_{x}$ and aerosols described in earlier studies. We then use MACC's Composition Integrated Forecasting System (C-IFS) model (Flemming et al., 2015) to quantify the relative impact of the dynamics and the biomass burning emissions on the ENSO signal in the $\mathrm{O}_{3}, \mathrm{CO}, \mathrm{NO}_{x}$ and smoke aerosol fields.

This paper is structured in the following way. Section 2 describes the MACC reanalysis and the ENSO signal seen in MACC $\mathrm{O}_{3}, \mathrm{CO}, \mathrm{NO}_{x}$ and smoke aerosol fields. Section $3 \mathrm{de}-$ scribes the additional C-IFS model runs that were carried out to quantify the relative impact of the dynamics and biomass burning emission on the ENSO signal in the atmospheric composition fields and their results, and Sect. 4 presents conclusions and outlook.

\section{ENSO signal in the MACC reanalysis}

\subsection{The MACC reanalysis}

The MACC data assimilation system provides analyses and forecasts of atmospheric composition and was used to produce a reanalysis of atmospheric composition covering the years 2003 to 2012, as described in Inness et al. (2013). $\mathrm{O}_{3}$ retrievals from several instruments (including the Ozone 
Monitoring Instrument (OMI), SCanning Imaging Absorption spectroMeter for Atmospheric CHartographY (SCIAMACHY), Solar Backscatter Ultra-Violet (SBUV/2), Microwave Limb Sounder (MLS)), CO retrievals from Measurements of Pollution in the Troposphere (MOPITT) and the Infrared Atmospheric Sounding Interferometer (IASI), tropospheric $\mathrm{NO}_{2}$ columns from SCIAMACHY, and AOD from the Moderate Resolution Imaging Spectroradiometer (MODIS) were assimilated to constrain the atmospheric composition fields. For more information about the assimilated data sets and the quality of the $\mathrm{O}_{3}, \mathrm{CO}$, and $\mathrm{NO}_{x}$ fields produced by the analysis, see Inness et al. (2013). The aerosol analysis in the MACC reanalysis is similar to that described in Benedetti et al. (2009) and Morcrette et al. (2011) and is based on four-dimensional variational assimilation of AOD observations at $550 \mathrm{~nm}$ from the MODIS sensors, including a global adaptive bias correction. Comparisons of multiyear averages of AOD over the period 2003-2010 from the MACC reanalysis and from the Multi-angle Imaging SpectroRadiometer (MISR) sensors onboard the Terra satellite indicate good qualitative agreement (not shown).

The anthropogenic emissions for the reactive gases for the MACC reanalysis were taken from the MACCity (MACC/CityZEN EU projects) inventory (Granier et al., 2011) which accounts for projected trends in the emissions. For the aerosol fields they came from the EDGAR database (Dentener et al., 2006). Monthly biomass burning emission for the years 2003 to 2008 from the Global Fire Emissions Database version 3.0 (GFED3.0) inventory (van der Werf et al., 2010) were scaled to daily resolution using MODIS active fire observations. From 2009 to 2012 daily biomass burning emissions from MACC's Global Fire Assimilation System (GFAS), version 1.0 (Kaiser et al., 2012) were used. One advantage of the MACC reanalysis is that it used daily fire emissions, in contrast to several other studies that used monthly averages. Biogenic emissions used in the MACC reanalysis were for 2003. They came from a recent update (Barkley, 2010) of the Model of Emissions of Gases and Aerosols from Nature version 2 (MEGAN2; Guenther et al., 2006, http://acd.ucar.edu/_guenther/MEGAN/MEGAN.htm) and were used as monthly surface flux fields without interannual variation.

The emissions are injected at the surface and distributed over the boundary layer by the model's convection and vertical diffusion scheme. Despite the distribution being very efficient, this is a limitation of the current system that will be addressed in future versions. Experiments have been carried out with a new version that uses injection heights based on the Plume Rise Model of Paugam et al. (2015). They show a significant impact on BC AOD for single large fires; the impact at a global scale is smaller: BC AOD is increased by around $5 \%$. Most of the injection heights calculated with the Plume Rise Model lie within the boundary layer and only a small fraction of smoke (often from particularly intense and well-studied fires) is injected directly into the free tropo- sphere. The largest smoke transport from the boundary layer to the free troposphere occurs through larger-scale meteorological processes. The lowering of the boundary layer height, when air is advected from land to sea, and strong updrafts in the frontal system have previously been identified as efficient smoke transport mechanisms. Similarly, Veira et al. (2015) has studied the sensitivity of AOD in a global climate model to different injection height parameterisations and the abovementioned plume rise model, with the conclusion that a simple parameterisation reproduces the average larger-scale distribution sufficiently well.

The MACC models do not contain halogenated species, which would contribute a small additional loss term to $\mathrm{O}_{3}$ and $\mathrm{CO}$. Ocean emissions of volatile organic compounds (VOCs) originate from climatological data from POET. Deposition on the ocean surface depends on the species solubility, which is negligible for $\mathrm{O}_{3}$ and $\mathrm{CO}$, but not for some of the VOCs. All these aspects may contribute to overall biases in the model, but are not considered essential for the signals investigated here.

Initial validation results from the MACC reanalysis are shown in Inness et al. (2013) and Morcrette et al. (2011) and a more detailed validation can be found in the MACC reanalysis validation reports available from http://atmosphere.copernicus.eu/services/aqac/global_ verification/validation_reports/.

\subsection{ENSO anomalies}

The MACC reanalysis was used to construct monthly composites of $\mathrm{O}_{3}, \mathrm{CO}, \mathrm{NO}_{x}$ fields at $500 \mathrm{hPa}$ and of the smoke $\mathrm{AOD}$, i.e. the sum of black carbon (BC) and organic matter (OM) AOD, at $550 \mathrm{~nm}$ for El Niño and La Niña years for the months October, November and December. The El Niño composite was constructed from the years 2004, 2006, 2009, and the La Niña composite from the years 2005, 2007, 2008, 2010, and 2011. Weak El Niño and La Niña years were included in the composite calculation to increase the sample size. A recent time series of the Multivariate ENSO index which was used to define the years used in our El Niño and La Niña composites can be found at http://www.esrl.noaa. gov/psd/enso/mei/index.html. Composites of vertical velocity and specific humidity at $500 \mathrm{hPa}$ were also calculated from the MACC reanalysis. SST and precipitation composite fields that were not available from the MACC reanalysis were constructed for the same years from the ERA Interim reanalysis (Dee et al., 2011), and biomass burning composites were calculated from the GFAS v1.0 data set. The composites were then used to calculated anomalies for the various fields by taking the difference between the El Niño and La Niña composites for the months October, November and December.

Figure 1 shows the warm SST anomaly over the central Pacific associated with El Niño conditions and the resulting precipitation changes for October, November and December 
a)

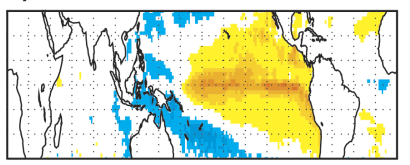

b)

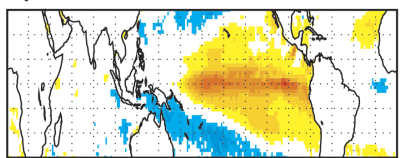

c)
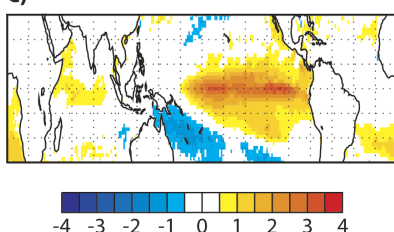

d)

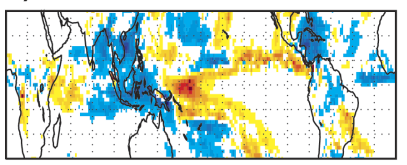

e)

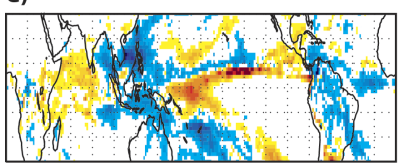

f)

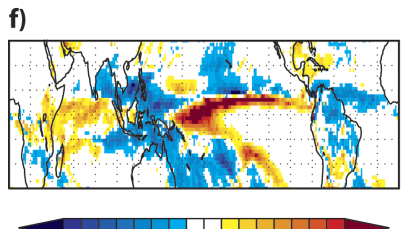

$\begin{array}{lllllllll}-4 & -3 & -2 & -1 & 0 & 1 & 2 & 3 & 4\end{array}$

Figure 1. Left panels: SST anomaly in K calculated from ERA Interim as the difference of El Niño composite minus La Niña composite for October (a), November (b) and December (c). Right panels: precipitation anomaly in $\mathrm{mm}$ /day calculated from ERA Interim as the difference of El Niño composite minus La Niña composite for October (d), November (e) and December (f). Red colours indicate positive values and blue colours negative values.

from ERA Interim. Precipitation is increased over the central Pacific and reduced over the western Pacific, Maritime Continent, northern Australia and part of the Indian Ocean. Figure 2 shows that the increased precipitation over the central Pacific and the reduced precipitation over the Maritime Continent are collocated with increased ascent and increased descent at $500 \mathrm{hPa}$, respectively. At the same time, specific humidity at $500 \mathrm{hPa}$ shows a positive anomaly in the area of increased ascent and precipitation over the central Pacific and a negative anomaly over the Maritime Continent. Cloud cover shows a similar signal to humidity, with a negative anomaly over the Maritime Continent and a positive anomaly over the central Pacific (not shown).

The increased biomass burning emissions related to the lack of rainfall over Indonesia and northern Australia can be seen in the fire radiative power (FRP) anomalies shown in Fig. 3. Increased fire activity can be seen over Indonesia in October and November, but stops by December after the end of the fire season, while a weaker biomass burning anomaly continues in northern Australia into December. Over Brazil decreased fire activity can be seen in October.

Figure 4 shows the IAV of the biomass burning emissions for CO from GFAS v1.0 for the 10 years covered by the MACC reanalysis for the area around Indonesia $\left(10^{\circ} \mathrm{N}-10^{\circ} \mathrm{S}, 90-130^{\circ} \mathrm{E}\right)$ and illustrates that the emissions are higher during the El Niño years 2004, 2006, 2009 than at other times. The largest values are seen for 2006. Table 1 shows the average $\mathrm{CO}, \mathrm{NO}_{x}$ and fire aerosol emissions from GFAS v1.0 during October, November, December for the El
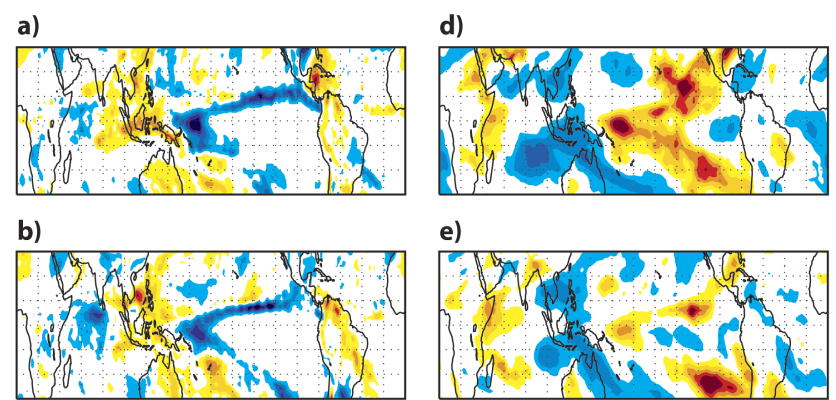

e)

c)
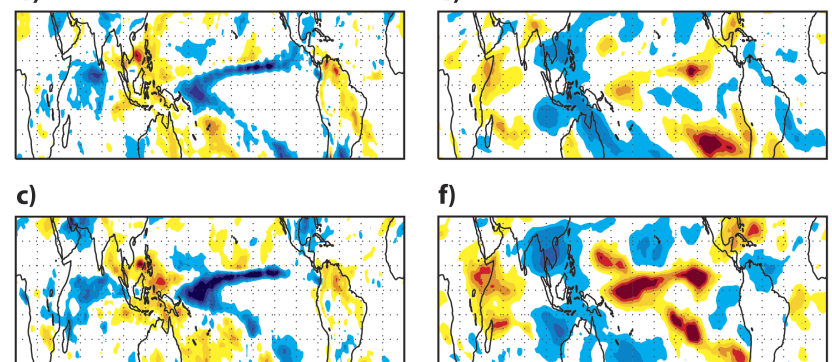

f)

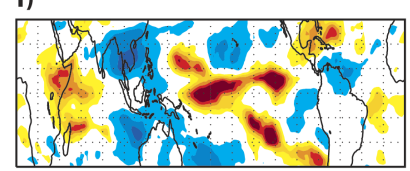

$\begin{array}{llllllllllll}-200 & -100 & -80 & -60 & -40 & -20 & 20 & 40 & 60 & 80 & 100 & 200\end{array}$

Figure 2. Left panels: anomaly of vertical velocity at $500 \mathrm{hPa}$ in $\mathrm{mm} \mathrm{s}^{-1}$ calculated from the MACC reanalysis as the difference of El Niño composite minus La Niña composite for October (a), November (b) and December (c). Blue colours show increased ascent, red colours increased descent. Right panels: specific humidity anomaly at $500 \mathrm{hPa}$ in percent calculated from the MACC reanalysis as the difference of El Niño composite minus La Niña composite for October (d), November (e) and December (f). Blue colours show reduced specific humidity, red colours increased values.

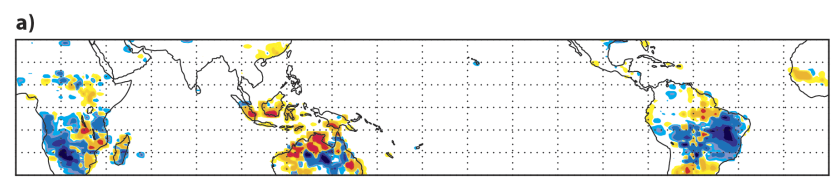

b)
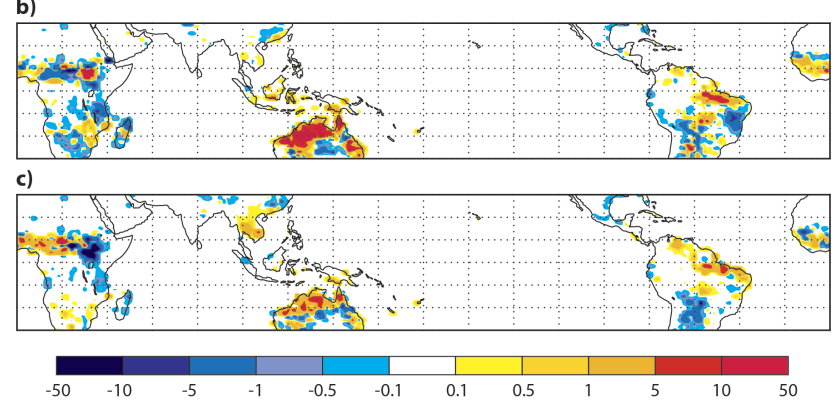

Figure 3. Biomass burning (fire radiative power areal density) anomaly in $\mathrm{mW} \mathrm{m}^{-2}$ calculated from the GFAS v1.0 data set as the difference of El Niño composite minus La Niña composite for October (a), November (b) and December (c). Red colours indicate positive values and blue colours negative values.

Niño years and La Niña years. The average CO emissions during El Niño years during October, November, and December are a factor of about 9,12, and 2 larger, respectively, than during La Niña years. For $\mathrm{NO}_{x}$, fire emissions are factors of 6, 6 and 2 greater and for smoke aerosols, factors of 9, 10 and 2 greater, respectively. The values in Table 1 are slightly smaller than the values in Chandra et al. (2009), who 


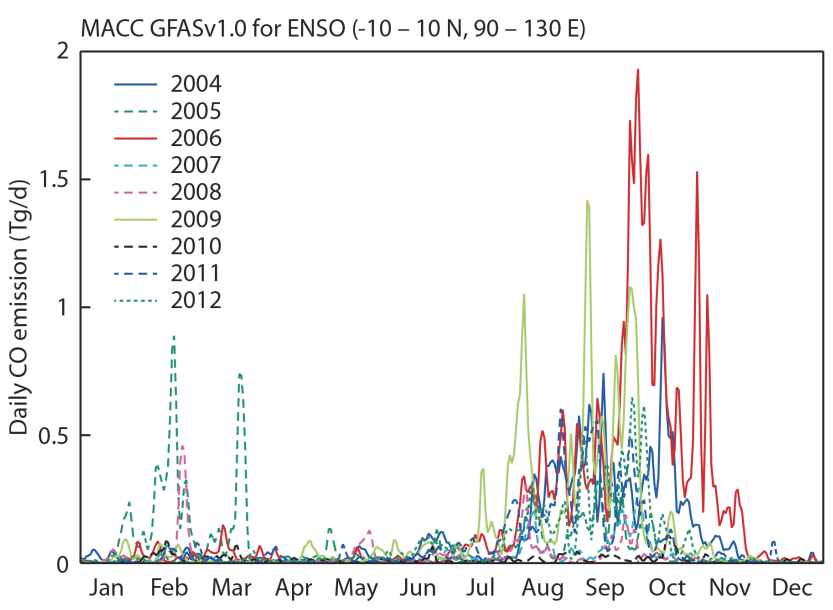

Figure 4. Time series of daily $\mathrm{CO}$ emissions in $\mathrm{Tg}\left(10^{12} \mathrm{~g}\right)$ per day from GFAS v1.0 for the region $10^{\circ} \mathrm{N}-10^{\circ} \mathrm{S}, 90-130^{\circ} \mathrm{E}$ for the years 2003 to 2012 .

list CO fire emissions over Indonesia as $44.2 \mathrm{Tg}_{\text {month }}{ }^{-1}$,

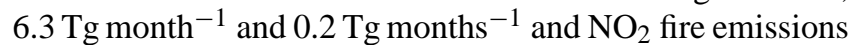
of $0.76,0.11$, and 0.0 for October, November, and December 2006, respectively.

Figures 5 to 8 illustrate the impact that the dynamical and emission-related changes have on the atmospheric composition fields, by showing the anomalies calculated from the MACC reanalysis at $500 \mathrm{hPa}$ for $\mathrm{O}_{3}, \mathrm{CO}, \mathrm{NO}_{x}$, and smoke AOD, respectively. $\mathrm{O}_{3}$ shows positive anomalies over the western Pacific, Indonesia, northern Australia and the eastern Indian Ocean, and negative anomalies over the central and eastern Pacific (Fig. 5). These anomalies are quite large scale and continue into December after the end of the biomass burning anomaly over Indonesia. The $\mathrm{O}_{3}$ anomalies agree well with those described in other studies based on MLS, Total Ozone Mapping Spectrometer (TOMS) (Chandra et al., 2009) and Tropospheric Emission Spectrometer (TES) data (Logan et al., 2008). The negative $\mathrm{O}_{3}$ anomaly over Africa and the western Indian Ocean in December was also noted by Nassar et al. (2009) in TES data and modelling studies with the Goddard Earth Observing System 3-D chemical transport model (GEOS-Chem), and we also note a negative $\mathrm{O}_{3}$ anomaly over Brazil in October. The $\mathrm{O}_{3}$ anomalies are a combination of biomass burning changes and meteorological changes as a consequence of changes in SSTs and the resulting eastward shift of the Walker circulation (Sudo and Takahashi, 2001; Chandra et al., 2002; Chandra et al., 2009). The $\mathrm{O}_{3}$ decrease over the central and eastern Pacific is due to enhanced upward transport of $\mathrm{O}_{3}$-poor air from the boundary layer into the middle and upper troposphere, and a shorter $\mathrm{O}_{3}$ lifetime and larger photochemical loss due to increased $\mathrm{H}_{2} \mathrm{O}$ (and hence $\mathrm{OH}$ ) concentrations.

During October and November, both dynamical and emission-driven effects contribute, and modelling studies (e.g. Sudo and Takahashi, 2001; Chandra et al., 2002; Chan-

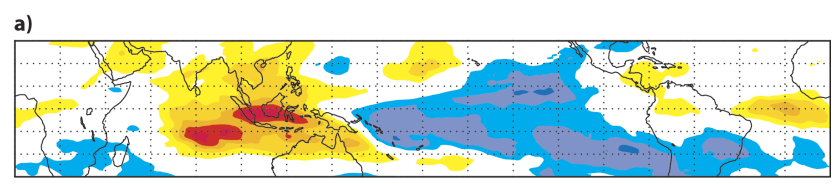

b)

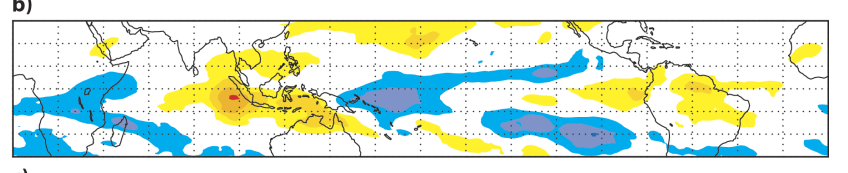

c)

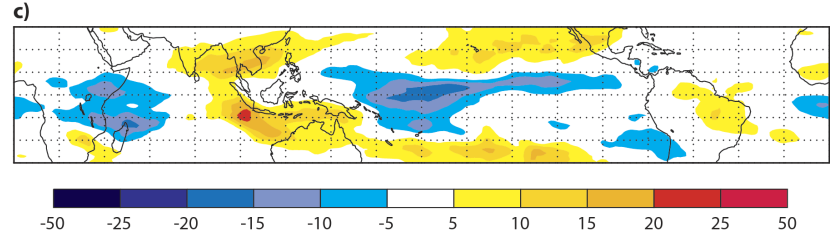

Figure 5. $\mathrm{O}_{3}$ anomaly at $500 \mathrm{hPa}$ in ppb calculated from the MACC reanalysis as the difference of El Niño composite minus La Niña composite for October (a), November (b) and December (c). Red colours indicate positive values and blue colours negative values.

dra et al., 2009) have shown that emissions and dynamical changes can contribute equally for El Niño years with strong biomass burning. The $\mathrm{O}_{3}$ changes in December are due to the dynamical changes after the end of the fire season over Indonesia. This agrees with what was seen by Logan et al. (2008), Chandra et al. (2009) and Nassar et al. (2009).

Figure 6 shows the $\mathrm{CO}$ anomalies at $500 \mathrm{hPa}$ calculated from the MACC reanalysis. These anomalies are more confined to the areas of the biomass burning anomalies (see Fig. 3) than the $\mathrm{O}_{3}$ anomalies (Fig. 5). The strongest positive anomaly is found over the Maritime Continent during October and is linked to increased emissions from enhanced biomass burning under drought conditions. A negative $\mathrm{CO}$ anomaly extends from South America over the South Atlantic to Africa in October and is related to lower fire emissions over Brazil. Similar anomalies were described by Logan et al. (2008), Nassar et al. (2009) and Chandra et al. (2009). The CO anomalies during November are weaker than the October ones, and by December the anomalies have all but disappeared. This confirms that the $\mathrm{CO}$ anomalies are mainly emission-driven and are not affected much by the dynamical changes that cause the $\mathrm{O}_{3}$ anomalies after the end of the biomass burning season in December.

The $\mathrm{NO}_{x}$ anomalies (Fig. 7) clearly show the impact of the increased emissions from biomass burning over Indonesia during October and November, but also seem to indicate some large-scale response. For example, the negative anomaly over the eastern Pacific is co-located with the negative $\mathrm{O}_{3}$ anomaly here (Fig. 5) and could indicate enhanced upward transport of $\mathrm{NO}_{x}$-poor air to these levels. Also the negative $\mathrm{NO}_{x}$ anomaly over the Pacific in December is again co-located with a (larger) negative $\mathrm{O}_{3}$ anomaly.

Figure 8 shows the anomaly of smoke AOD at $550 \mathrm{~nm}$ calculated from the MACC reanalysis. The largest positive 
Table 1. Biomass burning emissions in Tg per month for $\mathrm{CO}, \mathrm{NO}_{x}$, and the smoke aerosols (sum of organic matter and black carbon) from GFAS v1.0 for the region $10^{\circ} \mathrm{N}-10^{\circ} \mathrm{S}, 90-130^{\circ} \mathrm{E}$ averaged over the El Niño years $(2004,2006,2009)$ and the La Niña years $(2005,2007$, 2008, 2010, 2011), as well as the ratio of the El Niño/La Niña values.

\begin{tabular}{rrrrrrrrrr}
\hline & CO Oct & CO Nov & CO Dec & $\mathrm{NO}_{x}$ Oct & $\mathrm{NO}_{x}$ Nov & $\mathrm{NO}_{x}$ Dec & $\mathrm{OM}+\mathrm{BC}$ Oct & OM $+\mathrm{BC}$ Nov & OM $+\mathrm{BC}$ Dec \\
\hline El Niño & 13.9 & 3.0 & $2.4 \times 10^{-1}$ & $8.4 \times 10^{-2}$ & $1.9 \times 10^{-2}$ & $2.8 \times 10^{-3}$ & $6.3 \times 10^{-1}$ & $1.4 \times 10^{-1}$ & $1.3 \times 10^{-2}$ \\
La Niña & 1.5 & $2.5 \times 10^{-1}$ & $1.4 \times 10^{-1}$ & $1.4 \times 10^{-2}$ & $3.0 \times 10^{-3}$ & $1.5 \times 10^{-3}$ & $7.3 \times 10^{-2}$ & $1.4 \times 10^{-2}$ & $7.3 \times 10^{-3}$ \\
El Niño/ & 9.5 & 11.8 & 1.7 & 6.1 & 6.3 & 1.9 & 8.6 & 10.0 \\
La Niña & & & & & & & & 1.8 \\
\hline
\end{tabular}
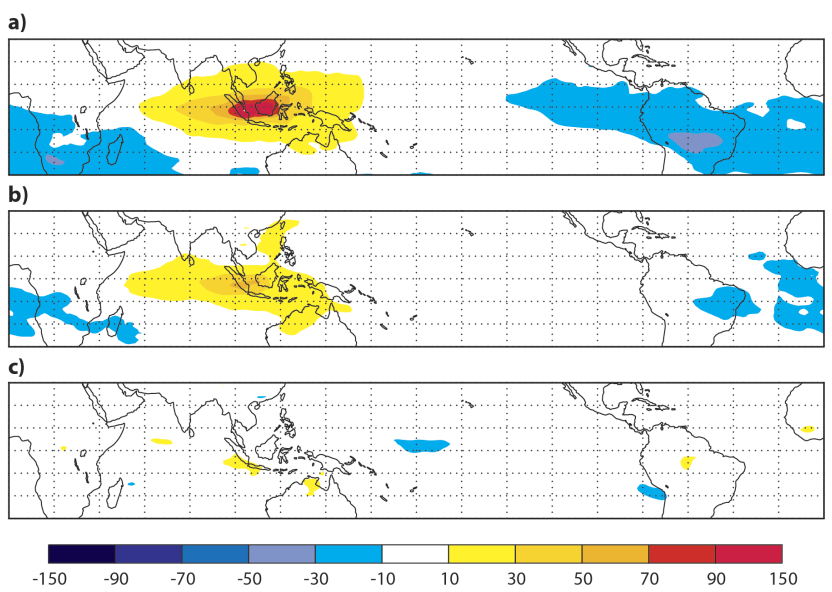

Figure 6. The same as Fig. 5 but for $\mathrm{CO}$ anomaly at $500 \mathrm{hPa}$ in ppb.
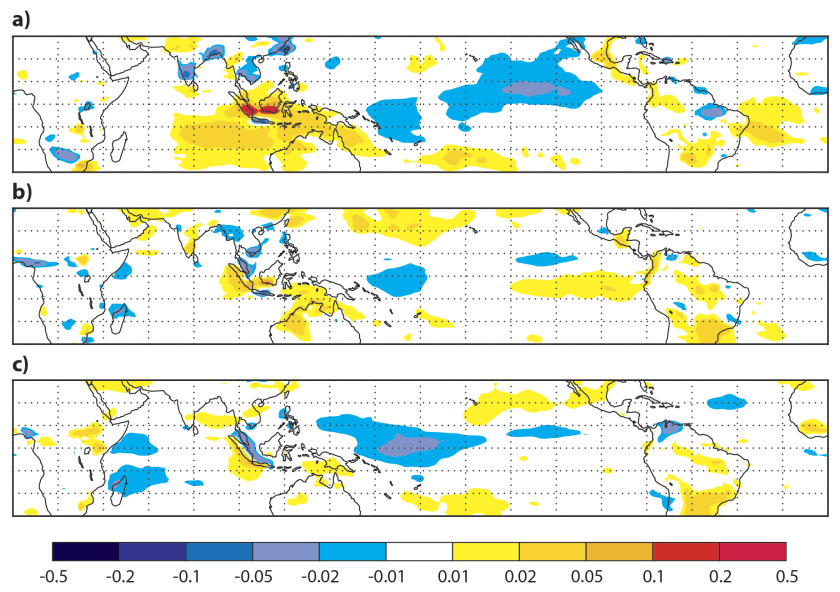

Figure 7. The same as Fig. 5 but for $\mathrm{NO}_{x}$ anomaly in ppb.

anomaly is found over Indonesia in October and November, corresponding to increased aerosol concentrations from biomass burning emissions. The negative aerosol anomaly over South America in October is related to the reduced fire activity seen in Fig. 3. By December the anomalies have disappeared. Similar AOD anomaly patterns over Indonesia were seen by Tosca et al. (2010) when comparing El Niño and La Niña years for August to October for the period 2000 and 2006 from the MISR and MODIS data.

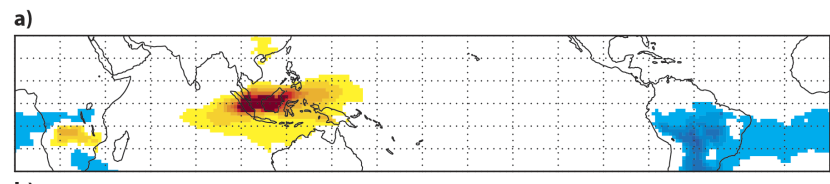

b)
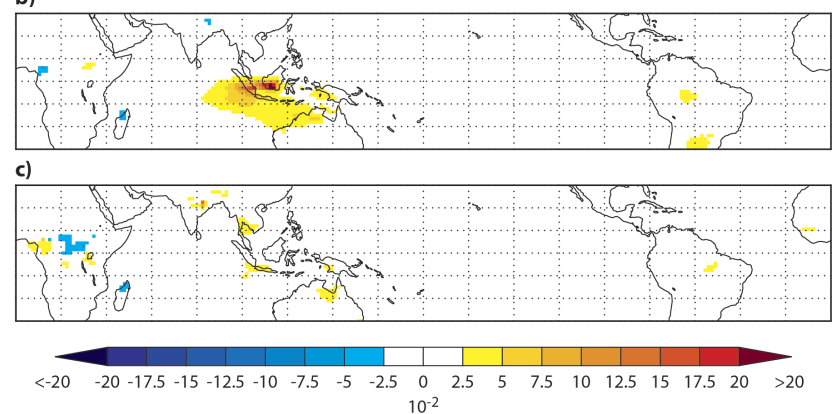

Figure 8. The same as Fig. 5 but for smoke AOD $(\mathrm{BC}+\mathrm{OM})$. AOD is unitless.

The three-dimensional nature of the MACC reanalysis allows us to look at the vertical distribution of the anomalies in the troposphere. Figures 9 to 12 show height versus longitude cross-sections of $\mathrm{O}_{3}, \mathrm{CO}, \mathrm{NO}_{x}$ and smoke AOD anomalies averaged over the latitude range of 0 to $12^{\circ} \mathrm{S}$. The $\mathrm{O}_{3}$ cross section in Fig. 9 illustrates that the largest positive $\mathrm{O}_{3}$ anomalies in October and November are located in the lower troposphere and are likely to be the result of enhanced $\mathrm{O}_{3}$ production due to increased concentrations of $\mathrm{O}_{3}$ precursors from enhanced fire emissions. However, the positive and negative anomalies extend into the upper troposphere, and some of the anomalies (for example the negative anomaly over the central Pacific) are clearly not connected to the surface but seem to originate in the middle or upper troposphere. These anomalies continue into December after the end of the fire season, and are likely to be a result of the dynamically induced changes mentioned above.

Figure 10 shows that $\mathrm{CO}$ anomalies are largest in the lower troposphere but can extend throughout the troposphere over Indonesia and South America. There is a clear connection to increased $\mathrm{CO}$ emissions over Indonesia and decreased emissions over South America due to changes in biomass burning. By December the anomalies have all but gone and show that there is no dynamically induced anomaly, unlike in $\mathrm{O}_{3}$. Now a small positive anomaly is found over South America. 


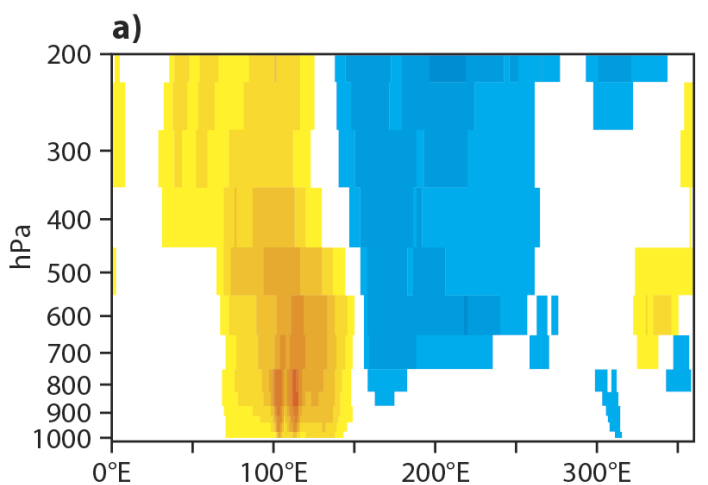

b)

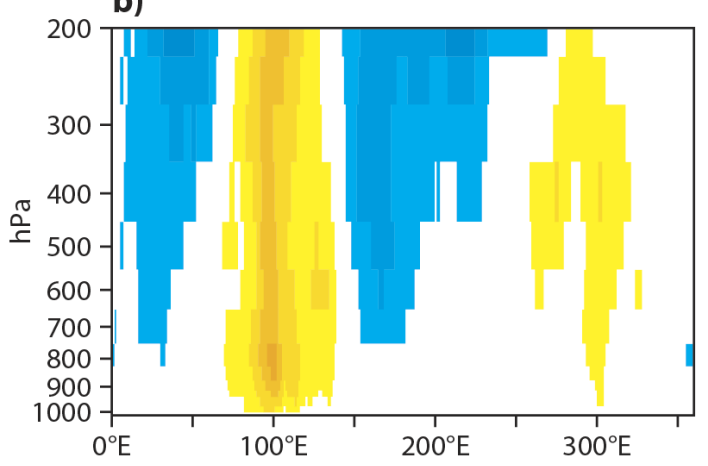

c)

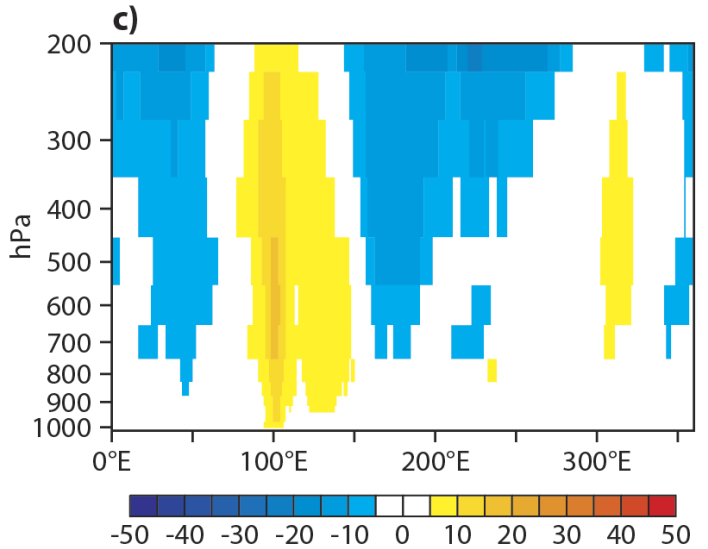

Figure 9. Vertical cross section of $\mathrm{O}_{3}$ anomalies in ppb plotted against longitude and averaged between $0^{\circ}$ and $12^{\circ} \mathrm{S}$ calculated from the MACC reanalysis as the difference of El Niño composite minus La Niña composite for October (a), November (b) and December (c). Red colours indicate positive values and blue colours negative values.

Figure 11 shows cross sections of $\mathrm{NO}_{x}$ anomalies calculated from the reanalysis. The largest anomalies are located in the lower troposphere and are again clearly connected to changes in the fire emissions. A large positive anomaly is found over Indonesia and negative anomalies over South America in October and Africa in October and November. In these areas there is reduced fire activity and increased precipitation during El Niño years. Positive $\mathrm{NO}_{x}$ anomalies are found in the upper troposphere and could be a result of in-

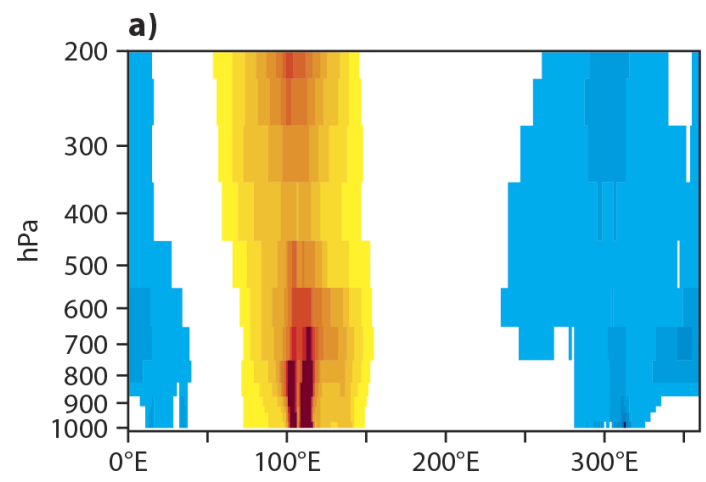

b)
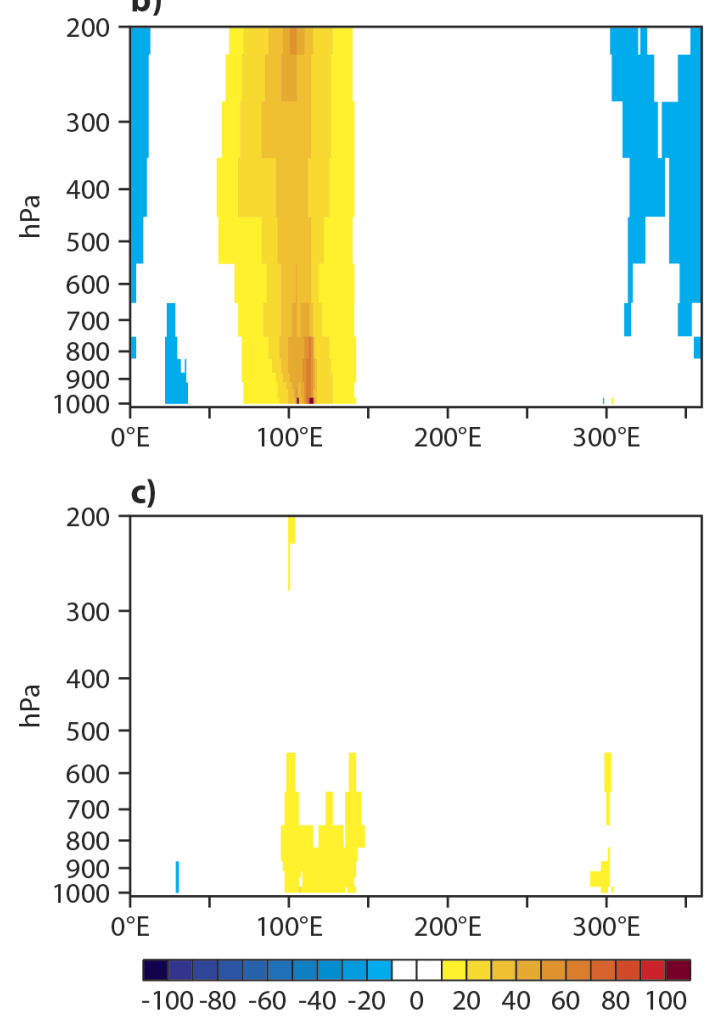

Figure 10. The same as Fig. 9 but for $\mathrm{CO}$ in ppb.

creased $\mathrm{NO}_{x}$ production from lightning over South America where there is positive precipitation anomaly pointing to increased convection. The flash rates in the lightning NO parameterisation are 5-10 larger over land than over ocean which might explain why no signal is seen over the central Pacific. The positive $\mathrm{NO}_{x}$ anomalies around $100^{\circ} \mathrm{E}$ in October and November are collocated with high $\mathrm{O}_{3}$ values in the lower troposphere (Fig. 9), pointing to enhanced $\mathrm{O}_{3}$ production due to enhanced $\mathrm{NO}_{x}$ concentrations from biomass burning. In December, when $\mathrm{NO}_{x}$ no longer shows such a positive anomaly, $\mathrm{O}_{3}$ concentrations in the lower troposphere are lower and the maximum of the $\mathrm{O}_{3}$ anomaly is located above $700 \mathrm{hPa}$. 
a)

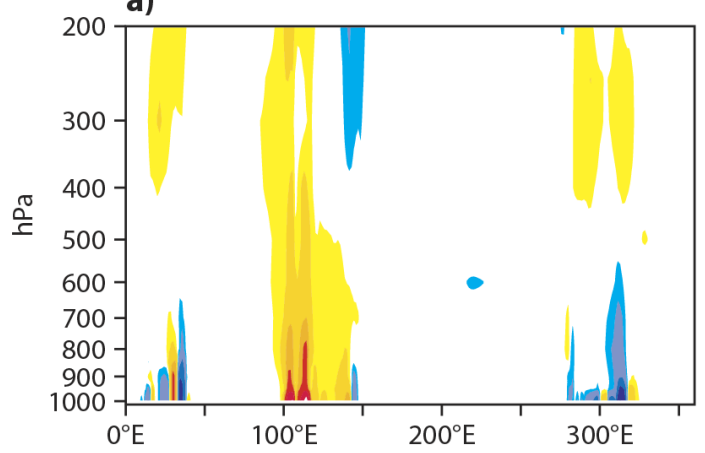

b)
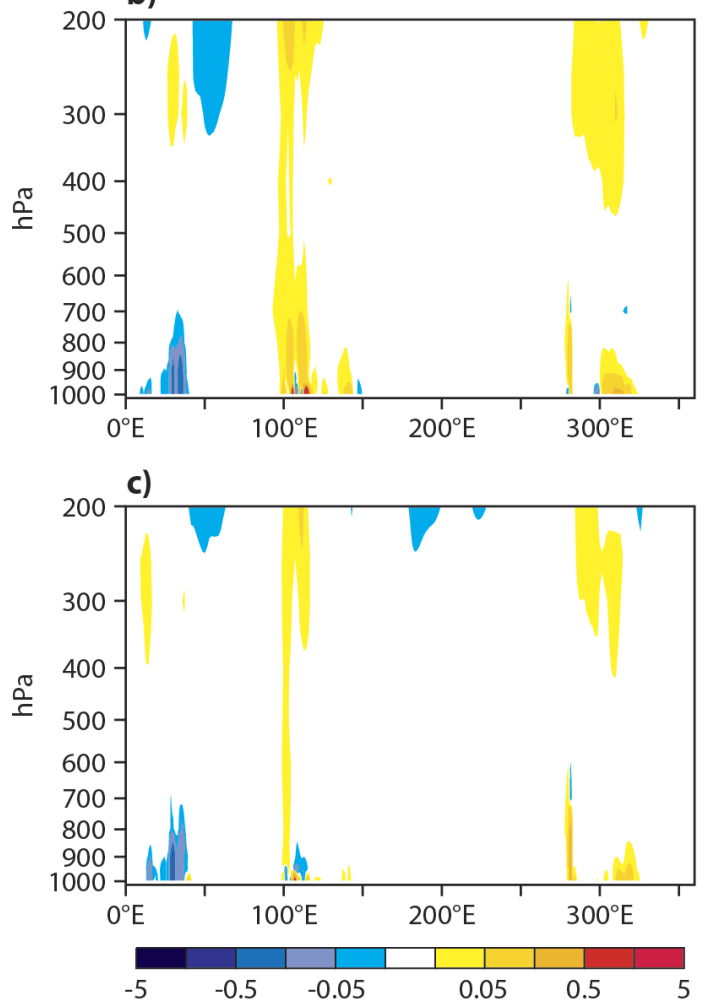

Figure 11. The same as Fig. 9 but for $\mathrm{NO}_{x}$ in ppb.

Figure 12 depicts cross sections of smoke AOD and shows that, as for $\mathrm{CO}$ and $\mathrm{NO}_{x}$, there is a clear connection to increased emissions over Indonesia in October and reduced emissions over South America. By December the positive anomaly over Indonesia is much reduced and confined to the lower troposphere. Enhanced AOD concentrations can be seen in November over South America. In the lower troposphere there is a negative aerosol anomaly over the central Pacific that is not seen in the other atmospheric composition fields. This anomaly is likely to be the result of the increased precipitation in this area during El Niño conditions (see Fig. 1) which leads to increased wet deposition and removal of aerosols, while not removing the gas-phase species in the same way.
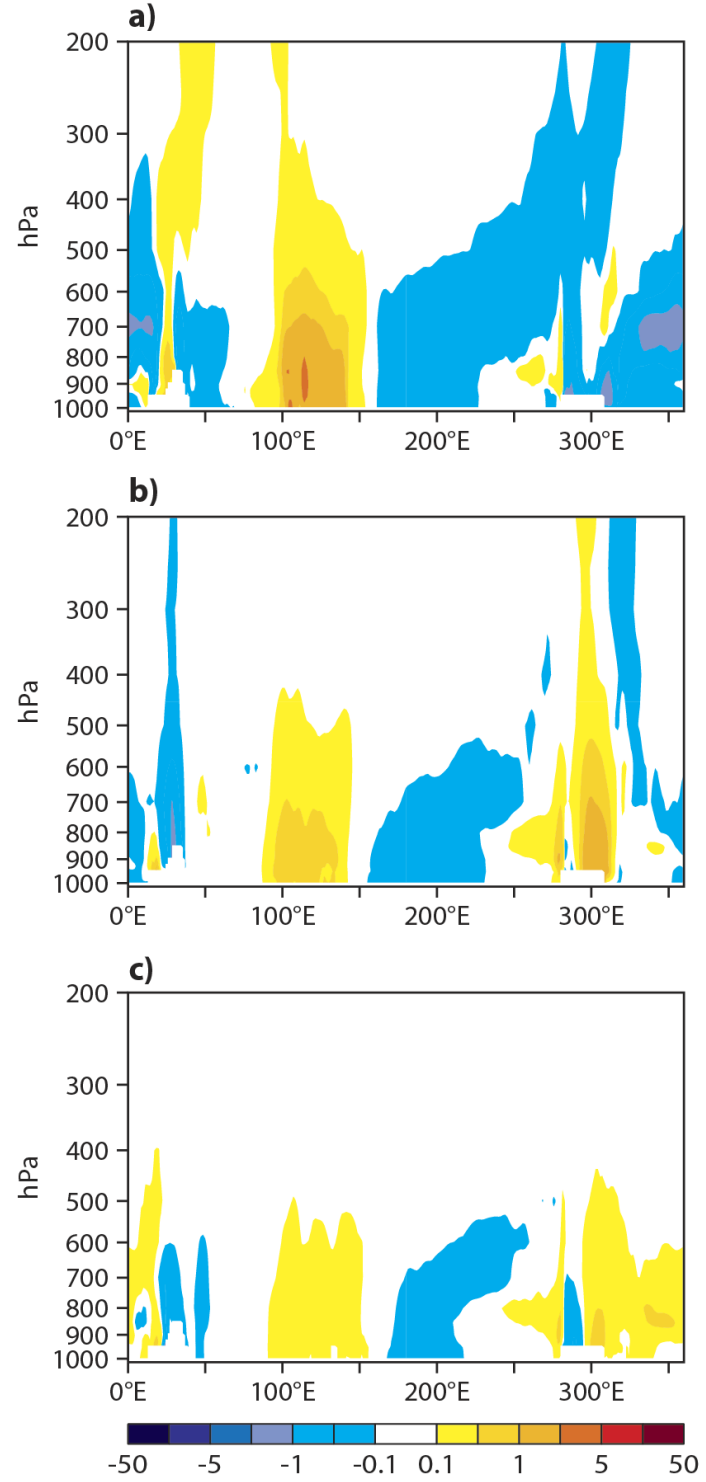

Figure 12. The same as Fig. 9 but for smoke aerosol in ppb.

\section{Quantifying the relative importance of dynamically induced and emission-driven changes on the atmospheric composition fields}

\subsection{Experiment setup}

To quantify the relative impact of increased biomass burning emissions and dynamically induced changes on the atmospheric composition fields during El Niño conditions, two experiments are run for the years 2005 and 2006: one with normal and one with climatological GFAS v1.0 fire emissions. 2006 was an El Niño year, and 2005 is used to represent normal to weak La Niña conditions. The additional experiments use the most recent version of the MACC system, the C-IFS model (Flemming et al., 2015; Inness et al., 2015). 
This model is different to the one used in the MACC reanalysis (Inness et al., 2013) because it has chemistry routines included directly in ECMWF's Integrated Forecasting System (IFS). A basic initial validation of C-IFS fields can be found in Flemming et al. (2015) and Inness et al. (2015) and more detailed validation of C-IFS can be found in the validation reports available from http://www.copernicus-atmosphere.eu/.

The chemistry scheme implemented in the C-IFS model version used for these experiments is an extended, modified version of the Carbon Bond Mechanism 5 (Yarwood et al., 2005) chemical mechanism as originally implemented in the chemistry transport model TM5 (Tracer Model 5) (Huijnen et al., 2010; Williams et al., 2013; Huijnen et al., 2014). This is a tropospheric chemistry scheme with 54 species and 126 reactions. For $\mathrm{O}_{3}$, a simple stratospheric parameterisation based on Cariolle and Teyssèdre (2007) has been added. Monthly mean dry deposition velocities are currently based on climatological fields from MOdèle de Chimie Atmosphérique à Grande Echelle (MOCAGE) (Michou et al., 2004). The module for wet deposition is based on the Harvard wet deposition scheme (Jacob et al., 2000; Liu et al., 2001). The output of the IFS convection scheme is used to calculate NO emissions from lightning. They are parameterised using estimates of the flash rate density, the flash energy release and the vertical emission profile. Estimates of the flash rate density are based on parameters of the convection scheme and calculated using convective precipitation as an input parameter (Meijer et al., 2001). Documentation of the technical implementation of C-IFS and more details about the model can be found in Flemming et al. (2015). In the present study, the C-IFS aerosol fields are not used in the radiation scheme, where an aerosol climatology based on Tegen et al. (1997) is used instead. Also, heterogeneous chemistry on aerosols is not included.

The anthropogenic emissions used in the C-IFS runs come from the MACCity emission database (Granier et al., 2011). Biogenic emissions are taken from the POET database for the year 2000 (Granier et al., 2005; Olivier et al., 2003), with isoprene emissions from MEGAN2.1, again for the year 2000 (Guenther et al., 2006). Biomass burning emissions for the runs are either taken from GFAS v1.0 (Kaiser et al., 2012) or from a GFAS v1.0 climatology. This daily climatology was constructed using the GFAS v1.0 data set from 2000 to 2014 (Kaiser et al., 2012; Remy and Kaiser, 2014). Biomass burning emissions for each day of the year were defined as the average of the emissions of the same day of the year for the 15 years of the data set.

The differences between the GFAS v1.0 and climatological GFAS emissions for the area $10^{\circ} \mathrm{N}-10^{\circ} \mathrm{S}, 90^{\circ} \mathrm{E}-130^{\circ} \mathrm{E}$ are shown in Fig. 13. The figure illustrates that 2006 was a year with exceptionally large biomass burning emissions over Indonesia during the biomass burning season (as already seen in Fig. 4), while in 2005 emissions were slightly below average.

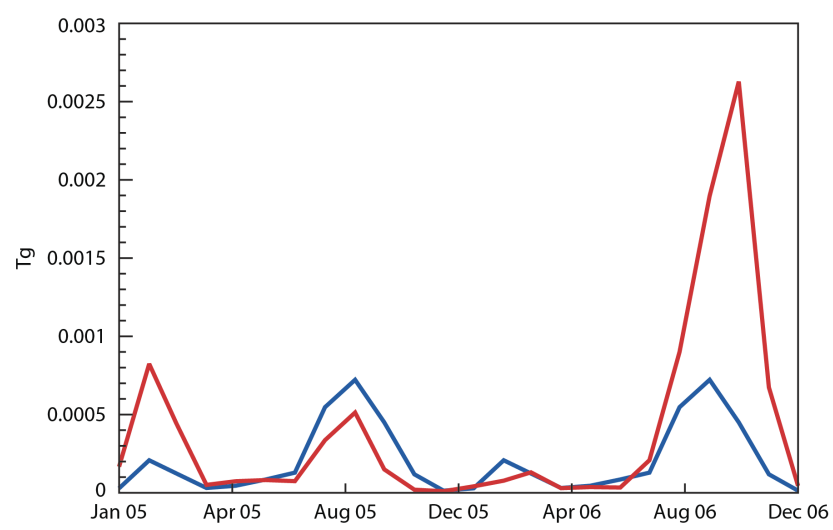

Figure 13. Time series of $\mathrm{CO}$ biomass burning emissions in $\mathrm{Tg}$ averaged over the region $10^{\circ} \mathrm{N}-10^{\circ} \mathrm{S}, 90^{\circ} \mathrm{E}-130^{\circ} \mathrm{E}$ from GFAS v1.0 (red) and climatological GFAS v1.0 data set (blue).

The experiments are started on 1 January 2005 and run until the end of 2006. The first experiment (BASE) uses daily GFAS v1.0 emissions, while the second experiment (CLIM) uses the climatological GFAS data set described above. We look at fields from these experiments for October and December 2005 and 2006 to determine

1. the overall impact of changes to the atmospheric composition fields due to El Niño-related dynamically and emission-induced changes by comparing BASE for the years 2006 and 2005 (BASE06 minus BASE05),

2. changes of atmospheric composition due to differences in biomass burning emissions under El Niño conditions by comparing BASE and CLIM for 2006 (BASE06 minus CLIM06),

3. the impact of the El Niño-induced dynamical changes on atmospheric composition and $\mathrm{O}_{3}$ production by comparing CLIM for the years 2006 and 2005 (CLIM06 minus CLIM05).

\subsection{Results of the C-IFS experiments}

Figure 14 shows time series of the tropospheric $\mathrm{CO}, \mathrm{O}_{3}$ and $\mathrm{NO}_{2}$ burdens from the BASE and CLIM experiments averaged over the area $10^{\circ} \mathrm{N}-10^{\circ} \mathrm{S}, 90^{\circ} \mathrm{E}-130^{\circ} \mathrm{E}$. Between September and November 2006 the GFAS v1.0 fire emissions used in BASE lead to an increased $\mathrm{CO}$ burden, which reaches values up to $21 \mathrm{Tg}$, almost double the values seen in CLIM (around $11 \mathrm{Tg}$ ). In 2005 the tropospheric CO burden in both experiments is similar to the CLIM values of 2006 (around 10-12 Tg). Tropospheric $\mathrm{O}_{3}$ burdens show a smaller increase (about $8 \%$ ) in 2006 from about $7.4 \mathrm{Tg}$ in CLIM to $8 \mathrm{Tg}$ in BASE. The $2006 \mathrm{O}_{3}$ burdens in BASE are increased by about $30 \%$ relative to 2005 , when the tropospheric $\mathrm{O}_{3}$ burden is about $6 \mathrm{Tg}$ in both experiments. It should be noted that the tropospheric $\mathrm{O}_{3}$ mass shows considerable intra-seasonal 
fluctuations. The tropospheric $\mathrm{NO}_{2}$ burden in BASE is increased by about 20-30\% compared to CLIM in September 2006 as a result of the increased fire emissions. During 2005 $\mathrm{NO}_{2}$ burdens from BASE and CLIM are of similar magnitude.

The top panels of Fig. 15 show the overall impact of changes to the tropospheric $\mathrm{O}_{3}$ column due to dynamically induced and emission-driven changes, by comparing BASE06 and BASE05 for October and December. The patterns are very similar to the ones seen in the MACC reanalysis composite $\mathrm{O}_{3}$ anomalies at $500 \mathrm{hPa}$ (Fig. 5). The combined effect of dynamically induced and emission-driven changes leads to an increase of $\mathrm{TCO}_{3}$ by over $50 \%$ in a large area surrounding Indonesia and to a reduction of 10-30\% over large parts of the central Pacific. $\mathrm{TCO}_{3}$ values are also reduced by more than $30 \%$ over Brazil. $\mathrm{TCO}_{3}$ changes due to changes in the fire emissions alone (middle panels of Fig. 15) can only explain part of the observed $\mathrm{O}_{3}$ increase over Indonesia (which is consistent with the small differences between BASE and CLIM seen in Fig. 14 for September to November 2006) and a small decrease over Brazil, and can not explain the reduction of $\mathrm{O}_{3}$ over the Pacific. The dynamically induced changes in October (Fig. 15, bottom left) show a similar pattern to the overall differences between El Niño and normal conditions. This illustrates that while emissiondriven changes can explain about half of the total $\mathrm{TCO}_{3}$ changes in a small area surrounding Indonesia, the $\mathrm{TCO}_{3}$ increase outside this region and the negative $\mathrm{O}_{3}$ anomaly over the Pacific are unrelated to changes in the fire emissions. This is also confirmed by the December plots, when firerelated anomalies are no longer seen (Fig. 15, middle right). The dynamically driven $\mathrm{O}_{3}$ anomalies persist into December and can explain most of the $\mathrm{TCO}_{3}$ anomaly (Fig. 15, bottom right). Over Indonesia the $\mathrm{O}_{3}$ maxima are now located around $10^{\circ} \mathrm{N}$ and $10^{\circ} \mathrm{S}$, and over the Pacific they are slightly smaller scale than in October.

The importance of the dynamically driven ozone changes was also highlighted by Lin et al. (2014, 2015). Despite large El Niño enhancements to wildfire activity in equatorial Asia, the model sensitivity experiments in Lin et al. (2014) indicated that wildfire emissions are not the main driver of ENSO-related ozone variability observed at Mauna Loa, Hawaii. The dynamically induced eastward extension and equatorward shift of the subtropical jet stream during El Niño plays a key role on observed interannual variability of springtime lower tropospheric ozone at Mauna Loa. These shifts enhance long-range transport of Asian ozone and CO pollution towards the eastern North Pacific in winter and spring during El Niño. Lin et al. (2015) demonstrated a connection between springtime western US ozone air quality and jet characteristics associated with strong La Niña winters. They showed more frequent late spring deep stratospheric ozone intrusions when the polar jet stream meanders southward over the western United States as occurs following strong La Niña winters.
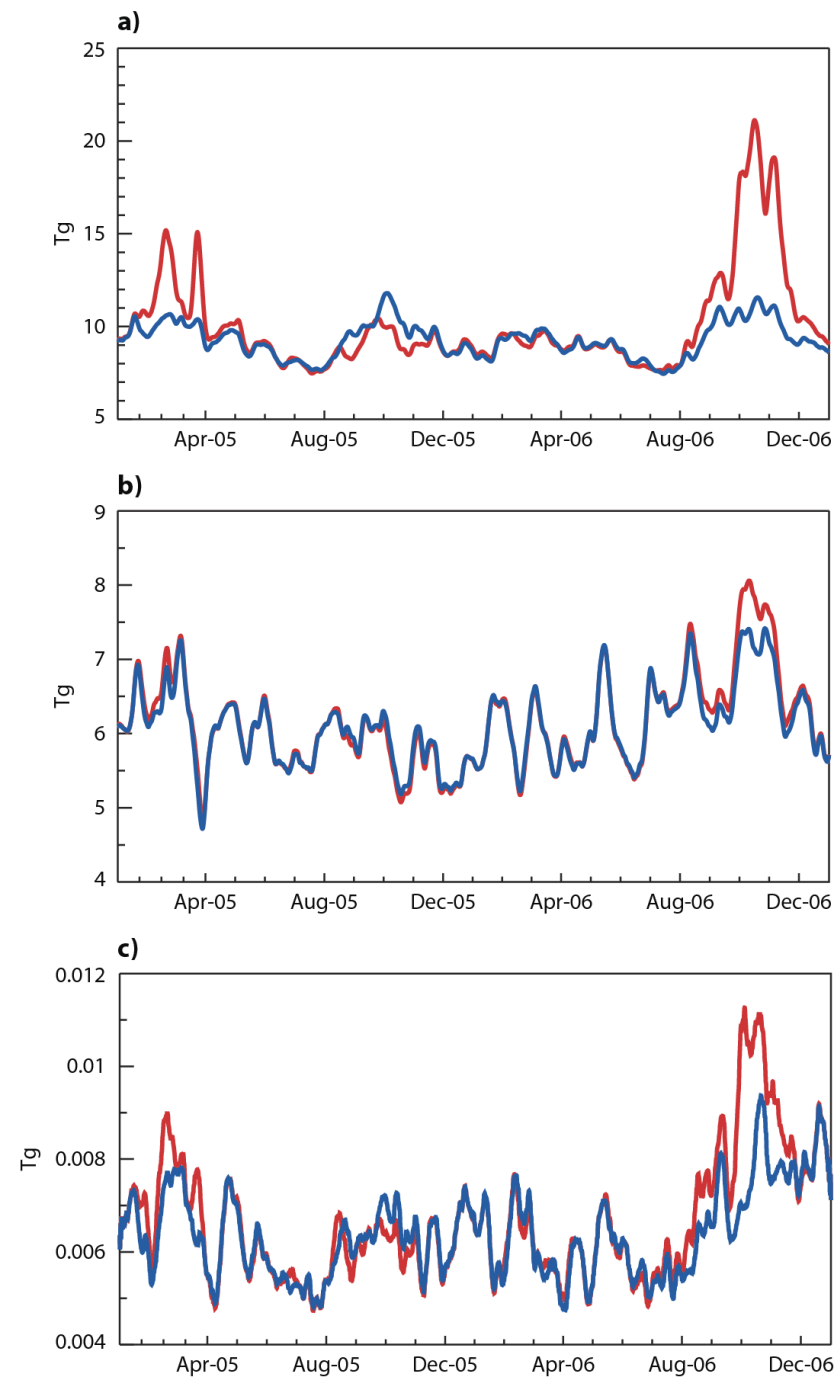

Figure 14. Time series of the tropospheric $\mathrm{CO}(\mathbf{a}), \mathrm{O}_{3}(\mathbf{b}), \mathrm{NO}_{2}$ (c) burden in Tg from BASE (red) and CLIM (blue) for 2005 and 2006 averaged over the area $10^{\circ} \mathrm{N}-10^{\circ} \mathrm{S}, 90^{\circ} \mathrm{E}-130^{\circ} \mathrm{E}$.

The $\mathrm{TCO}_{3}$ changes seen in the bottom panel of Fig. 15 are anti-correlated with changes in specific humidity (Fig. 16, top panels) pointing to an enhanced $\mathrm{O}_{3}$ lifetime over Indonesia due to reduced humidity and hence $\mathrm{OH}$ concentrations. Furthermore, there is enhanced ascent over the central Pacific and enhanced descent over Indonesia (Fig. 16, bottom panels) so that increased upward transport of clean $\mathrm{O}_{3}$-poor air over the Pacific and increased downward transport from the upper troposphere/stratosphere in the Indonesian region will also affect the tropospheric $\mathrm{O}_{3}$ columns. In October the peak in specific humidity is located south of the ozone enhancement. This agrees with Nassar et al. (2009), who showed that the equatorial component of the October ozone anomaly was related to fire emissions, while the southern component of the ozone anomaly was due to other factors. It should be noted that the positive specific humidity anomalies over the Ara- 

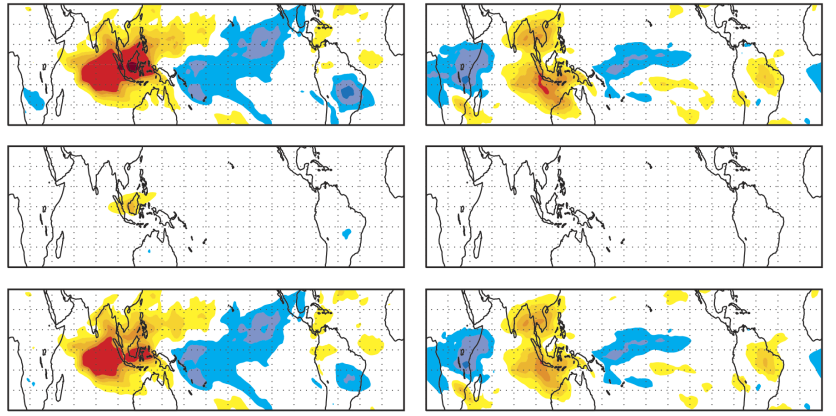

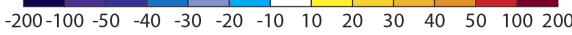

Figure 15. $\mathrm{TCO}_{3}$ differences in percent for October (left) and December (right) from the experiments BASE06-BASE05 (top), BASE06-CLIM06 (middle) and CLIM06-CLIM05 (bottom). The top panels show the overall differences of $\mathrm{TCO}_{3}$ due to the combined effects of El Niño-related dynamical changes and changes in the fires emissions between El Niño and normal conditions. The middle panels show the impact of changes to the fire emissions under El Niño conditions, and the bottom panels show the impact of the El Niño-induced dynamical changes on $\mathrm{TCO}_{3}$ when climatological fire emissions are used for both years. Red colours indicate positive values and blue colours negative values.

bian Peninsula and over Australia in October do not correspond to decreased ozone values, while the ones over southern Africa, South America and the central Pacific do. The reason for this is that relative anomalies are shown and that the absolute humidity values over the Arabian Peninsula and Australia are much lower than in the other areas, so that the absolute humidity changes between 2006 and 2005 are actually relatively small. This all suggests that the correlation of $\mathrm{O}_{3}$ to specific humidity is strongest in tropical regions with large variability in water vapour, combined with low $\mathrm{NO}_{x}$ conditions.

Figure 17 shows that the total column $\mathrm{CO}$ (TCCO) anomalies over Indonesia are almost entirely emission-driven, in contrast to the $\mathrm{TCO}_{3}$ anomalies seen in Fig. 15. Using GFAS v1.0 emissions rather than climatological GFAS emissions can explain most of the TCCO anomaly over Indonesia in October, apart from two small positive dynamically induced anomalies to the east and west of the Maritime Continent. By December, after the end of the fire season in Indonesia, the TCCO anomalies are almost gone.

As for $\mathrm{CO}$, the $\mathrm{NO}_{2}$ and smoke aerosol anomalies are entirely emission-driven (not shown). For both these fields, no anomalies are seen when comparing CLIM06 and CLIM05, and the anomalies seen when comparing BASE06 and BASE05 are gone by December. It is possible that we could have also see some dynamically induced changes in the smoke aerosols if aerosols were interactive with the radiation scheme in the model runs. However, without this feedback the smoke aerosol anomalies are entirely emission-driven.
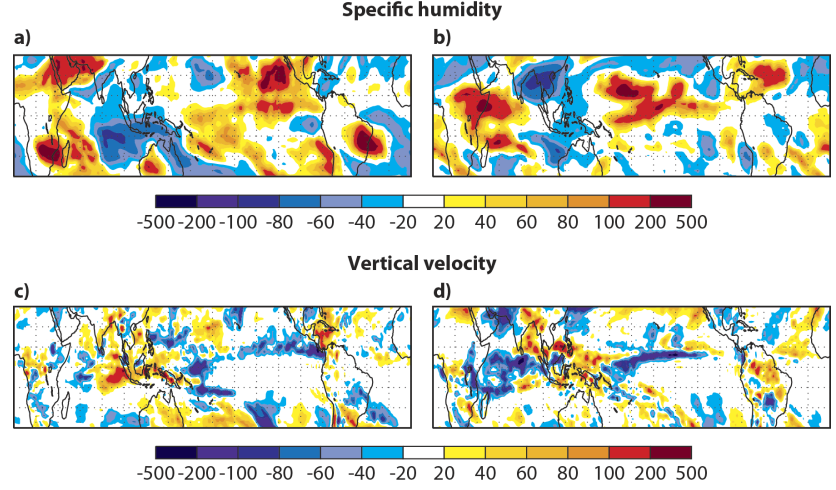

Figure 16. Top panels: specific humidity differences at $500 \mathrm{hPa}$ in percent for October (a) and December (b) from the experiments BASE06 minus BASE05. Blue colours show reduced specific humidity, red colours increased values. Bottom panels: differences of vertical velocity in $\mathrm{mm} \mathrm{s}^{-1}$ for October (c) and December (d) from the experiments BASE06 minus BASE05. Blue colours show increased ascent, red colours increased descent.
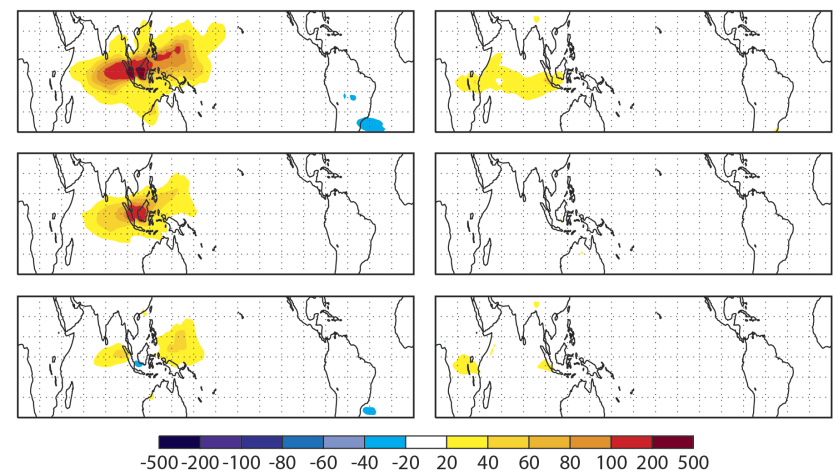

Figure 17. TCCO differences in percent for October (left) and December (right) from the experiments BASE06-BASE05 (top), BASE06-CLIM06 (middle) and CLIM06-CLIM05 (bottom). Red colours indicate positive values and blue colours negative values.

Figure 18 shows $\mathrm{O}_{3}-\mathrm{CO}$ correlations for October 2005 and 2006 from the BASE and CLIM experiments. We focus only on October as the month with the largest anomaly in the fire emissions. Such correlations have been used in several studies (e.g. Kim et al., 2013; Voulgarakis et al., 2011, and references therein) going back to Fishman and Seiler (1983) to identify regions of photochemically produced $\mathrm{O}_{3}$ (positive correlations) and $\mathrm{O}_{3}$ from other sources (e.g. downward transport from stratosphere) as well as $\mathrm{O}_{3}$ loss due to chemistry or deposition (negative correlations). In 2005, free tropospheric $\mathrm{O}_{3}-\mathrm{CO}$ correlations (Fig. 18 a and c) show a similar distribution across the Maritime Continent with relatively weak $(r<0.7)$ negative correlations extending from the Indian Ocean south of Indonesia to East and West Malaysia and the Philippines, and positive correlations over northern and eastern Indonesia. Slight differences in the distribution of the $\mathrm{O}_{3}-\mathrm{CO}$ correlations between Fig. 18a and c reflect dif- 
a)

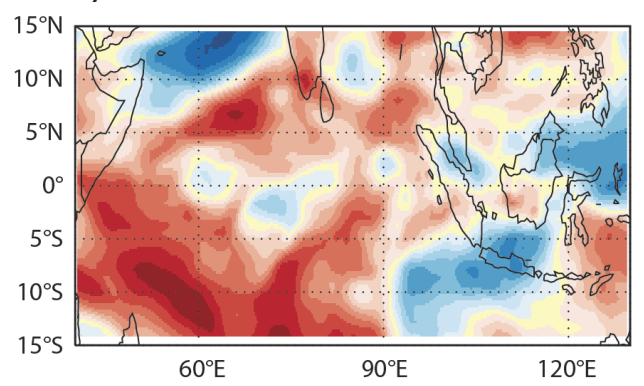

c)

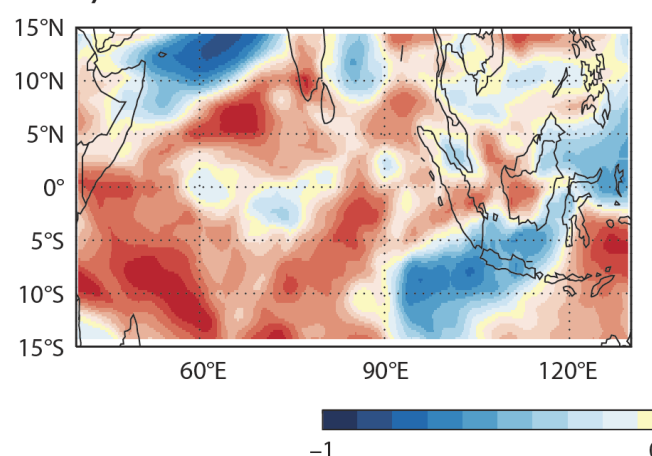

b)

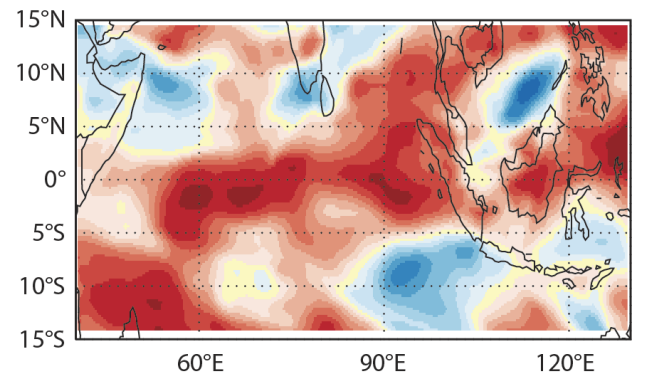

d)

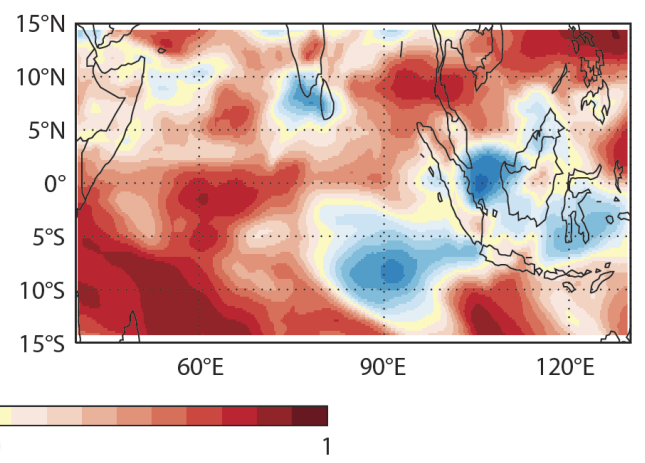

Figure 18. October $\mathrm{O}_{3}-\mathrm{CO}$ correlations calculated for free tropospheric (approx. $750-350 \mathrm{hPa}$ ) column abundances over the Maritime Continent from the BASE (top) and CLIM (bottom) experiments for 2005 (left) and 2006 (right). Red colours indicated positive correlations and blue colours negative ones.

ferences in the fire emissions between the BASE and CLIM experiments. Larger differences are seen in the distribution of free tropospheric $\mathrm{O}_{3}-\mathrm{CO}$ correlations between BASE and CLIM for the El Niño year of 2006 (Fig. 18 b and d). The increased fire activity in 2006 (Figs. 4 and 13) gives rise to larger positive $(r>0.7) \mathrm{O}_{3}-\mathrm{CO}$ correlations extending across most of Indonesia and Malaysia in the BASE experiment (Fig. 18b) and reflects enhanced $\mathrm{O}_{3}$ photochemistry associated with increased emissions of $\mathrm{O}_{3}$ precursors from the fires. This agrees well with the area of increased $\mathrm{O}_{3}$ concentrations due to fires seen in Fig. 16 when comparing BASE06 and CLIM06. In contrast, $\mathrm{O}_{3}-\mathrm{CO}$ correlations in the CLIM experiment (Fig. 18d) are generally negative over much of Indonesia and Malaysia and reflect the influence of transport across the region and the lack of enhanced $\mathrm{O}_{3}$ production when the climatological fire emissions are used.

\section{Conclusions and outlook}

In this paper $\mathrm{O}_{3}, \mathrm{CO}, \mathrm{NO}_{x}$ and smoke aerosol fields from the MACC reanalysis (Inness et al., 2013) were used to identify the ENSO signal in tropical atmospheric composition fields, concentrating on the months October to December. The MACC atmospheric composition fields show a clear ENSO-related anomaly signal with increased $\mathrm{O}_{3}, \mathrm{CO}, \mathrm{NO}_{x}$ and smoke aerosols over the Maritime Continent during El
Niño years. $\mathrm{O}_{3}$ also shows larger-scale changes with decreased tropospheric columns over the central and eastern Pacific and increased columns over the western Pacific and the Maritime Continent that continue after the end of the Indonesian fire season.

Two simulations were carried out with the C-IFS model to quantify to what extent the ENSO signal seen in the atmospheric composition fields was due to changes in biomass burning emissions or due to dynamically induced changes, e.g. related to changes in the vertical transport of $\mathrm{O}_{3}$ from the lower troposphere and the stratosphere, and to changes of the photolysis of $\mathrm{O}_{3}$ due to changes to $\mathrm{OH}$. While the $\mathrm{CO}, \mathrm{NO}_{2}$ and smoke aerosol changes were almost entirely driven by changes in biomass burning emissions due to increased wild fires over the Maritime Continent during El Niño-related drought conditions, changes in tropospheric $\mathrm{O}_{3}$ were largely dynamically induced and only in small part driven by changes in the emissions. The emission-driven $\mathrm{O}_{3}$ changes were confined to the area surrounding Indonesia, where enhanced photochemical $\mathrm{O}_{3}$ production occurs under El Niño conditions because of increased biomass burning activities, while the larger-scale $\mathrm{O}_{3}$ anomalies were dynamically induced.

Comparing simulations with daily GFAS v1.0 emissions for the years 2005 and 2006 and a daily GFAS v1.0 climatology of the period 2000 to 2014 showed that tropospheric CO was almost doubled in September 2006 relative to September 
2005 due to increased fire emissions; $\mathrm{NO}_{2}$ was increased by $20-30 \%$ and $\mathrm{O}_{3}$ by about $8 \%$. For tropospheric $\mathrm{O}_{3}$, dynamically induced changes dominated the differences between 2006 and 2005. The fire-induced $\mathrm{O}_{3}$ anomaly was smaller in magnitude and horizontal extent than the dynamically induced changes which affected much of the tropics. In 2006, tropospheric $\mathrm{O}_{3}$ was increased by more than $50 \%$ over the Maritime Continent and Indian Ocean compared to 2005, and decreased by between 20 and $30 \%$ over large parts of the tropical Pacific when the same climatological fire emissions were used in both years. Only in a small area over Indonesia was the $\mathrm{O}_{3}$ increase due to fires of similar magnitude to the dynamically induced changes. A future study will look in more detail at the chemistry budgets and chemical processes that cause the changes in the atmospheric composition fields.

The results from this paper show that the MACC system is able to model changes in atmospheric composition fields found under El Niño and La Niña conditions. After a more thorough validation of the MACC atmospheric fields against observations, it could be interesting to investigate the oceanatmosphere response to ENSO-induced changes in atmospheric composition in a further study. A first step would be to include the aerosol direct and indirect effects through the cloud microphysics in the radiation scheme of the IFS and to look at the feedback of fire-induced aerosols on climate. We would expect positive feedback, i.e. reduced convection due to increased atmospheric stability, as carbonaceous aerosols usually absorb (and thus re-emit) a significant amount of solar radiation in the mid-troposphere, and increased aerosol concentrations also lead to reduced land and sea surface temperatures. Their presence should therefore act to reduce convection and precipitation over the Maritime Continent. Including the aerosols in the radiation scheme will also affect the chemical fields through changes in the UV radiation and hence photolysis rates. A second step could see the coupling of the chemistry and aerosol fields by including heterogeneous chemistry on aerosols. In a final step, the MACC system could be coupled with ECMWF's ocean model to investigate how the forcing from ENSO-induced changes to atmospheric composition fields feeds back into the ENSO dynamics.

MACC atmospheric composition data are freely available from www.copernicus-atmosphere.eu.

Acknowledgements. MACC-II was funded by the European Commission under the EU Seventh Research Framework Programme, contract no. 283576. MACC-III was funded by the European Commission under Horizon2020 as a Coordination \& Support Action, grant agreement no. 633080 .

Edited by: P. Jöckel

\section{References}

Allan, R. J., Lindesay, J., and Parker D. E.: El Niño Southern Oscillation and climatic variability, 416 pp., CSIRO Publishing, Collingwood, Victoria, Australia, 1996.

Aouizerats, B., van der Werf, G. R., Balasubramanian, R., and Betha, R.: Importance of transboundary transport of biomass burning emissions to regional air quality in Southeast Asia during a high fire event, Atmos. Chem. Phys., 15, 363-373, doi:10.5194/acp-15-363-2015, 2015.

Barkley, M.: Description of MEGAN biogenic VOC emissions in GEOS-Chem, available at: http://acmg.seas.harvard.edu/geos/ wiki_docs/emissions/megan.pdf (last access: 11 May 2015), 2010.

Benedetti, A., Morcrette, J.-J., Boucher, O., Dethof, A., Engelen, R. J., Fisher, M., Flentje, H., Huneeus, N., Jones, L., Kaiser, J. W., Kinne, S., Mangold, A., Razinger, M., Simmons, A. J., Suttie, M., and the GEMS-AER team: Aerosol analysis and forecast in the European Centre for Medium-Range Weather Forecasts Integrated Forecast System: 2. Data assimilation, J. Geophys. Res., 114, D13205, doi:10.1029/2008JD011115, 2009.

Cariolle, D. and Teyssèdre, H.: A revised linear ozone photochemistry parameterization for use in transport and general circulation models: multi-annual simulations, Atmos. Chem. Phys., 7, 2183 2196, doi:10.5194/acp-7-2183-2007, 2007.

Chandra, S., Ziemke, J. R., Min, W., and Read, W. G.: Effects of 1997-1998 El Niño on tropospheric ozone. Geophys. Res. Lett., 25, 3867-3870, 1998.

Chandra, S., Ziemke, J. R., Bhartia, P. K., and Martin, R. V.: Tropical tropospheric ozone: Implications for dynamics and biomass burning, J. Geophys. Res., 107, 4188, doi:10.1029/2001JD000447, 2002.

Chandra, S., Ziemke, J. R., Schoeberl, M. R., Froidevaux, L., Read, W. G., Levelt, P. F., and Bhartia, P. K.: Effects of the 2004 El Niño on tropospheric ozone and water vapour. Geophys. Res. Lett., 34, L06802, doi:10.1029/2006GL028779, 2007.

Chandra, S., Ziemke, J. R., Duncan, B. N., Diehl, T. L., Livesey, N. J., and Froidevaux, L.: Effects of the 2006 El Niño on tropospheric ozone and carbon monoxide: implications for dynamics and biomass burning, Atmos. Chem. Phys., 9, 4239-4249, doi:10.5194/acp-9-4239-2009, 2009.

Chung, C. E. and Ramanathan, V.: South Asian haze forcing: Remote impacts with implications to ENSO and AO, J. Climate, 16, 1791-1806, 2003

Dee, D. P., Uppala, S. M., Simmons, A. J., Berrisford, P., Poli, P., Kobayashi, S., Andrae, U., Balmaseda, M. A., Balsamo, G., Bauer, P., Bechtold, P., Beljaars, A. C. M., van de Berg, L., Bidlot, J., Bormann, N., Delsol, C., Dragani, R., Fuentes, M., Geer, A. J., Haimberger, L., Healy, S. B., Hersbach, H., Hölm, E. V., Isaksen, L., Kållberg, P., Köhler, M., Matricardi, M., McNally, A. P., Monge-Sanz, B. M., Morcrette, J.-J., Park, B.-K., Peubey, C., de Rosnay, P., Tavolato, C., Thépaut, J.-N., and Vitarta, F.: The ERA-Interim reanalysis: configuration and performance of the data assimilation system, Q. J. Roy. Meteor. Soc., 137, 553597, 2011.

Dentener, F., Kinne, S., Bond, T., Boucher, O., Cofala, J., Generoso, S., Ginoux, P., Gong, S., Hoelzemann, J. J., Ito, A., Marelli, L., Penner, J. E., Putaud, J.-P., Textor, C., Schulz, M., van der Werf, G. R., and Wilson, J.: Emissions of primary aerosol and precursor gases in the years 2000 and 1750 prescribed data-sets for Ae- 
roCom, Atmos. Chem. Phys., 6, 4321-4344, doi:10.5194/acp-64321-2006, 2006.

Doherty, R. M., Stevenson, D. S., Johnson, C. E., Collins, W. J., and Sanderson, M. G.: Tropospheric ozone and El Niño-Southern Oscillation: Influence of atmospheric dynamics, biomass burning emissions, and future climate change, J. Geophys. Res., 111, D19304, doi:10.1029/2005JD006849, 2006.

Duncan, B. N., Bey, I., Chin, M., Mickley, L. J., Fairlie, T. D., Martin, R. V., and Matsueda, H.: Indonesian wildfires of 1997: Impact on tropospheric chemistry, J. Geophys. Res., 108, 4458, doi:10.1029/2002JD003195, 2003.

Fishman, J. and Seiler, W.: Correlative nature of ozone and carbon monoxide in the troposphere: Implications for the tropospheric ozone budget, J. Geophys. Res., 88, 3662-3670, doi:10.1029/JC088iC06p03662, 1983.

Flemming, J., Huijnen, V., Arteta, J., Bechtold, P., Beljaars, A., Blechschmidt, A.-M., Diamantakis, M., Engelen, R. J., Gaudel, A., Inness, A., Jones, L., Josse, B., Katragkou, E., Marecal, V., Peuch, V.-H., Richter, A., Schultz, M. G., Stein, O., and Tsikerdekis, A.: Tropospheric chemistry in the Integrated Forecasting System of ECMWF, Geosci. Model Dev., 8, 975-1003, doi:10.5194/gmd-8-975-2015, 2015.

Fujiwara, M., Kita, K., Kawakami, S., Ogawa, T., Komala, N., Saraspriya, S., and Suripto, A.: Tropospheric ozone enhancements during the Indonesian forest fire events in 1994 and in 1997 as revealed by ground-based observations, Geophys. Res. Lett., 26, 2417-2420, 1999.

Granier, C., Guenther, A., Lamarque, J., Mieville, A., Muller, J., Olivier, J., Orlando, J., Peters, J., Petron, G., Tyndall, G., and Wallens, S.: POET, a database of surface emissions of ozone precursors, available at: http://www.aero.jussieu.fr/projet/ ACCENT/POET.php (last access: December 2014), 2005.

Granier, C., Bessagnet, B., Bond, T., D’ Angiola, A., Denier van der Gon, H., Frost, G. J., Heil, A., Kaiser, J. W., Kinne, S., Klimont, Z., Kloster, S., Lamarque, J.-F., Liousse, C., Masui, T., Meleux, F., Mieville, A., Ohara, R., Raut, J.-C., Riahi, K., Schultz, M. G., Smith, S. G., Thompson, A., van Aardenne, J., van der Werf, G. R., and van Vuuren, D. P.: Evolution of anthropogenic and biomass burning emissions of air pollutants at global and regional scales during the 1980-2010 period, Clim. Change, 109, 163-190, doi:10.1007/s10584-011-0154-1, 2011.

Guenther, A., Karl, T., Harley, P., Wiedinmyer, C., Palmer, P. I., and Geron, C.: Estimates of global terrestrial isoprene emissions using MEGAN (Model of Emissions of Gases and Aerosols from Nature), Atmos. Chem. Phys., 6, 3181-3210, doi:10.5194/acp-63181-2006, 2006.

Hauglustaine, D. A., Brasseur, G. P. , Walters, S., Rasch, P. J., Müller, J.-F., Emmons, L. K., and Carroll, M. A.: MOZART, a global chemical transport model for ozone and related chemical tracers, 2, Model results and evaluation, J. Geophys. Res., 103, 28291-28335, 1999.

Huijnen, V., Williams, J., van Weele, M., van Noije, T., Krol, M., Dentener, F., Segers, A., Houweling, S., Peters, W., de Laat, J., Boersma, F., Bergamaschi, P., van Velthoven, P., Le Sager, P., Eskes, H., Alkemade, F., Scheele, R., Nédélec, P., and Pätz, H.-W.: The global chemistry transport model TM5: description and evaluation of the tropospheric chemistry version 3.0, Geosci. Model Dev., 3, 445-473, doi:10.5194/gmd-3-445-2010, 2010.
Huijnen, V., Williams, J. E., and Flemming, J.: Modeling global impacts of heterogeneous loss of $\mathrm{HO}_{2}$ on cloud droplets, ice particles and aerosols, Atmos. Chem. Phys. Discuss., 14, 8575-8632, doi:10.5194/acpd-14-8575-2014, 2014.

Inness, A., Baier, F., Benedetti, A., Bouarar, I., Chabrillat, S., Clark, H., Clerbaux, C., Coheur, P., Engelen, R. J., Errera, Q., Flemming, J., George, M., Granier, C., Hadji-Lazaro, J., Huijnen, V., Hurtmans, D., Jones, L., Kaiser, J. W., Kapsomenakis, J., Lefever, K., Leitão, J., Razinger, M., Richter, A., Schultz, M. G., Simmons, A. J., Suttie, M., Stein, O., Thépaut, J.-N., Thouret, V., Vrekoussis, M., Zerefos, C., and the MACC team: The MACC reanalysis: an 8 yr data set of atmospheric composition, Atmos. Chem. Phys., 13, 4073-4109, doi:10.5194/acp-13-4073-2013, 2013.

Inness, A., Blechschmidt, A.-M., Bouarar, I., Chabrillat, S., Crepulja, M., Engelen, R. J., Eskes, H., Flemming, J., Gaudel, A., Hendrick, F., Huijnen, V., Jones, L., Kapsomenakis, J., Katragkou, E., Keppens, A., Langerock, B., de Mazière, M., Melas, D., Parrington, M., Peuch, V. H., Razinger, M., Richter, A., Schultz, M. G., Suttie, M., Thouret, V., Vrekoussis, M., Wagner, A., and Zerefos, C.: Data assimilation of satelliteretrieved ozone, carbon monoxide and nitrogen dioxide with ECMWF's Composition-IFS, Atmos. Chem. Phys., 15, 52755303, doi:10.5194/acp-15-5275-2015, 2015.

Jacob, D. J., Liu, H., Mari, C., and Yantosca, R. M.: Harvard wet deposition scheme for GMI, Harvard University Atmospheric Chemistry Modeling Group, revised March 2000, available at: http://acmg.seas.harvard.edu/geos/wiki_docs/deposition/ wetdep.jacob_etal_2000.pdf (last access: December 2014), 2000.

Kaiser, J. W., Heil, A., Andreae, M. O., Benedetti, A., Chubarova, N., Jones, L., Morcrette, J.-J., Razinger, M., Schultz, M. G., Suttie, M., and van der Werf, G. R.: Biomass burning emissions estimated with a global fire assimilation system based on observed fire radiative power, Biogeosciences, 9, 527-554, doi:10.5194/bg-9-527-2012, 2012.

Kim, P. S., Jacob, D. J., Liu, X., Warner, J. X., Yang, K., Chance, K., Thouret, V., and Nedelec, P.: Global ozone-CO correlations from OMI and AIRS: constraints on tropospheric ozone sources, Atmos. Chem. Phys., 13, 9321-9335, doi:10.5194/acp-13-93212013, 2013.

Liu, H., Jacob, D. J., Bey, I., and Yantosca, R. M.: Constraints from $210 \mathrm{~Pb}$ and $7 \mathrm{Be}$ on wet deposition and transport in a global three-dimensional chemical tracer model driven by assimilated meteorological fields, J. Geophys. Res., 106, 1210912129, doi:10.1029/2000JD900839, 2001.

Logan, J. A., Megretskaia, I., Nassar, R., Murray, L. T., Zhang, L., Bowman, K. W., Worden, H. M., and Luo, M.: Effects of the 2006 El Niño on tropospheric composition as revealed by data from the Tropospheric Emission Spectrometer (TES), Geophys. Res. Lett., 35, L03816, doi:10.1029/2007GL031698, 2008.

Lyon, B.: The strength of El Niño and the spatial extent of tropical drought, Geophys. Res. Lett., 31, L21204, doi:10.1029/2004GL020901, 2004.

Meijer, E. W., van Velthoven, P. F. J., Brunner, D. W., Huntrieser, H., and Kelder, H.: Improvement and evaluation of the parameterisation of nitrogen oxide production by lightning, Phys. Chem. Earth Pt. C, 26, 577-583, 2001. 
Lin, M., Fiore, A. M., Horowitz, L. W., Langford, A. O., Oltmans, S. J., Tarasick, D., and Rieder, H. E.: Climate variability modulates western US ozone air quality in spring via deep stratospheric intrusions, Nature Communications, 6, 7105, doi:10.1038/ncomms8105, 2015.

Lin, M., Horowitz, L. W., Oltmans, S. J., Fiore, A. M., and Fan, S.: Tropospheric ozone trends at Manna Loa Observatory tied to decadal climate variability, Nat. Geosci., 7, 136-143, doi:10.1038/NGEO2066, 2014.

Michou M., Laville, P., Serça, D., Fotiadi, A., Bouchou P., and Peuch, V.-H.: Measured and modeled dry deposition velocities over the ESCOMPTE area, Atmos. Res., 74, 89-116, 2004.

Morcrette, J.-J., Benedetti, A., Jones, L., Kaiser, J. W., Razinger, M., and Suttie, M.: Prognostic aerosols in the ECMWF IFS: MACC vs GEMS aerosols. ECMWF RD Tech. Memo 659, available at: http://old.ecmwf.int/publications/library/ecpublications/_pdf/ tm/601-700/tm659.pdf (last access: January 2015), 2011.

Nassar, R., Logan, J. A., Megretskaia, I. A., Murray, L. T., Zhang, L., and Jones, D. B. A.: Analysis of tropical tropospheric ozone, carbon monoxide, and water vapor during the 2006 El Niño using TES observations and the GEOS-Chem model, J. Geophys. Res., 114, D17304, doi:10.1029/2009JD011760, 2009.

Olivier, J., Peters, J., Granier, C., Petron, G., Müller, J., and Wallens, S.: Present and future surface emissions of atmospheric compounds, POET report \#2, EU project EVK2-1999-00011, available at: http://www.aero.jussieu.fr/projet/ACCENT/POET. php (last access: December 2014), 2003.

Page, S. E., Siegert, F., Rieley, J. O., Boehm, H. D., Jaya, A., and Limin, S.: The amount of carbon released from peat and forest fires in Indonesia during 1997, Nature, 420, 61-65, doi:10.1038/nature01131, 2002.

Paugam, R., Wooster, M., Atherton, J., Freitas, S. R., Schultz, M. G., and Kaiser, J. W.: Development and optimization of a wildfire plume rise model based on remote sensing data inputs - Part 2, Atmos. Chem. Phys. Discuss., 15, 9815-9895, doi:10.5194/acpd-15-9815-2015, 2015.

Podgorny, I. A., Li, F., and Ramanathan, V.: Large Aerosol Radiative Forcing due to the 1997 Indonesian Forest Fire, Geophys. Res. Lett., 30, 1028, doi:10.1029/2002GL015979, 2003.

Remy, S. and Kaiser, J. W.: Daily global fire radiative power fields estimation from one or two MODIS instruments, Atmos. Chem. Phys., 14, 13377-13390, doi:10.5194/acp-14-13377-2014, 2014.

Sudo, K. and Takahashi, M.: Simulation of tropospheric ozone changes during 1997-1998 El Niño: Meteorological impact on tropospheric photochemistry, Geophys. Res. Lett., 28, 40914094, 2001.

Tegen, I., Hollrig, P., Chin, M., Fung, I., Jacob, D., and Penner, J.: Contribution of different aerosol species to the global aerosol extinction optical thickness: Estimates from model results, J. Geophys. Res., 102, 23895-23915, 1997.
Tosca, M. G., Randerson, J. T., Zender, C. S., Flanner, M. G., and Rasch, P. J.: Do biomass burning aerosols intensify drought in equatorial Asia during El Niño?, Atmos. Chem. Phys., 10, 35153528, doi:10.5194/acp-10-3515-2010, 2010.

van der Werf, G. R., Randerson, J. T., Giglio, L., Collatz, G. J., Kasibhatla, P. S., and Arellano Jr., A. F.: Interannual variability in global biomass burning emissions from 1997 to 2004, Atmos. Chem. Phys., 6, 3423-3441, doi:10.5194/acp-6-3423-2006, 2006.

van der Werf, G. R., Randerson, J. T., Giglio, L., Collatz, G. J., Mu, M., Kasibhatla, P. S., Morton, D. C., DeFries, R. S., Jin, Y., and van Leeuwen, T. T.: Global fire emissions and the contribution of deforestation, savanna, forest, agricultural, and peat fires (19972009), Atmos. Chem. Phys., 10, 11707-11735, doi:10.5194/acp10-11707-2010, 2010.

Veira, A., Kloster, S., Schutgens, N. A. J., and Kaiser, J. W.: Fire emission heights in the climate system - Part 2: Impact on transport, black carbon concentrations and radiation, Atmos. Chem. Phys., 15, 7173-7193, doi:10.5194/acp-15-7173-2015, 2015.

Voulgarakis, A., Savage, N. H., Wild, O., Braesicke, P., Young, P. J., Carver, G. D., and Pyle, J. A.: Interannual variability of tropospheric composition: the influence of changes in emissions, meteorology and clouds, Atmos. Chem. Phys., 10, 2491-2506, doi:10.5194/acp-10-2491-2010, 2010.

Voulgarakis, A., Telford, P. J., Aghedo, A. M., Braesicke, P., Faluvegi, G., Abraham, N. L., Bowman, K. W., Pyle, J. A., and Shindell, D. T.: Global multi-year $\mathrm{O}_{3}-\mathrm{CO}$ correlation patterns from models and TES satellite observations, Atmos. Chem. Phys., 11, 5819-5838, doi:10.5194/acp-11-5819-2011, 2011.

Wang, Y., Field, R. D., and Roswintiarti, O.: Trends in atmospheric haze induced by peat fires in Sumatra Island, Indonesia and El Niño phenomenon from 1973 to 2003, Geophys. Res. Lett., 31, L04103, doi:10.1029/2003GL018853, 2004.

Williams, J. E., van Velthoven, P. F. J., and Brenninkmeijer, C. A. M.: Quantifying the uncertainty in simulating global tropospheric composition due to the variability in global emission estimates of Biogenic Volatile Organic Compounds, Atmos. Chem. Phys., 13, 2857-2891, doi:10.5194/acp-13-2857-2013, 2013.

Yarwood, G., Rao, S., Yocke, M., and Whitten, G. Z.: Updates to the Carbon Bond Mechanism: CB05. US EPA Final Report, 161 pp., available at: http://www.camx.com/publ/pdfs/CB05_Final_ Report_120805.pdf (last access: December 2014), 2005.

Ziemke, J. R. and Chandra, S.: Seasonal and interannual variabilities in tropical tropospheric ozone, J. Geophys. Res., 104, 21425 21442, doi:10.1029/1999JD900277, 1999.

Ziemke, J. R. and Chandra, S.: La Niña and El Niño - induced variabilities of ozone in the tropical lower atmosphere during 1970-2001, Geophys. Res. Lett., 30, 1142, doi:10.1029/2002GL016387, 2003. 